\title{
The Political Economy of Investment in Human Capital *
}

\author{
José Pineda \\ Corporación Andina de Fomento \\ Francisco Rodríguez \\ Instituto de Estudios Superiores de Administración
}

November 18, 2004

\begin{abstract}
Investments in human capital accumulation, government consumption and total government expenditures present a striking negative correlation with capital shares. This correlation is robust to alternative specifications, lists of controls, and exclusion of outliers. Causality tests strongly support the hypothesis that the direction of causation runs from capital shares to the government spending variables. We present a political economy model of interest groups that can account for these correlations. In contrast, a median voter model predicts positive correlations between capital shares and the government spending variables.
\end{abstract}

\footnotetext{
*Corresponding author: Francisco Rodríguez, Associate Professor, Centro de Políticas Públicas, Instituto de Estudios Superiores de Administración, IESA POBA International \#646, PO Box 025255, Miami, FL 33102-5255. E_mail: francisco.rodriguez@iesa.edu.ve. The authors wish to thank Allan Drazen, Samuel Bowles, James Crotty, Jordan Rappaport, Eduardo Zambrano and participants at Seminars at UMass Amherst, George Mason, Maryland, Stanford and the AEA meetings for helpful comments and suggestions. The opinions expressed in this paper do not represent the views of IESA or the Corporación Andina de Fomento.
} 


\section{Introduction}

Differences in rates of investment in human capital across countries are substantial. While Haiti, Guatemala and Indonesia all spend less than $3 \%$ of their GDP in education and health expenditures, most OECD countries as well as some developing countries such as Costa Rica and Panama devote more than a tenth of GDP to it. These differences have potentially vast implications for economic growth and welfare. ${ }^{1}$ What are their sources? Can they be accounted for by variations in economic structure, or do differences in the political process across countries also matter?

This paper is an attempt to contribute to our understanding of why some societies devote more resources to investment in human capital than others. Our focus will be on the role that politics play in the determination of public investment in human capital. The strategy will be to contrast the predictions of the two main competing models of politics - the median voter model and the interest groups model - with the empirical evidence. We center on the explanatory power of these theories to explain the strong association that exists in the data between the factor distribution of income and investment in human capital: countries with lower labor shares are characterized by low levels both of investment in education and health and of redistributive government expenditures. This correlation is illustrated in Figures 1 and 2, which show the partial residual plots of public spending on education and public spending on health (as a percent of GDP) on capital shares. ${ }^{2}$ As we show below, this correlation is remarkably robust to changes in the list of controls, specification, and exclusion of outliers.

\footnotetext{
${ }^{1}$ Many cross-country regressions find the effect of the stock of human capital on economic growth to be significantly correlated with growth. For summaries of these results see Barro and Sala-i-Martin (1995), Barro (1997), and Aghion and Howitt (1998). This issue is, however, controversial; see in particular the views of Pritchett (1996) and Easterly (2001).

${ }^{2}$ The controls are the $\log$ of initial income per capita, log of total population, percentages of the population under 15 and over 65, initial life expectancy, and a set of continent and period dummies.
} 
It is not difficult to come up with plausible non-political economy explanations for this phenomenon. High capital shares may simply be a reflection of high levels of spending in investment in human capital coupled with high substitutability between capital and labor. Alternatively, increases in the efficiency of investment in human capital could simultaneously induce high capital shares and high investment in human capital, producing a spurious correlation between the two. However, as we argue in more detail in section 3, either of these alternative explanations does not fit the finer patterns in the data. In particular, changes in factor shares typically precede changes in investment in human capital, shedding doubt on the reverse causation hypothesis. Furthermore, the negative correlation between capital shares and investment in human capital is present for public yet not for private investment and is most marked when this investment has a strong redistributive component, making improbable the hypothesis that the observed correlations are ultimately linked to exogenous movements in the productivity of human capital.

It thus appears useful to explore the implications that alternative political economy theories have for investment in human capital, and to examine how consistent they are with the observed patterns in the data. In this paper we will contrast the explanatory power of what we view as the two main theories of politics: a theory of democratic politics that emphasizes the preferences of voters as the basic determinant of policies (the median voter theory) and a theory that gives a central role to the capacity of money to affect politics (the interest groups theory). We will argue that an interest groups theory is best poised to account for the patterns in the empirical evidence. The intuition is simple: Redistributive investment in human capital benefits those with more human capital. In the context of an interest groups model, an increase in the capital share is a shift of both economic and political resources to those whose income comes primarily from physical capital and thus have the least interest in investment in human capital. Therefore, when the capital share increases, the political equilibrium shifts towards the lower levels of investment in human capital desired by those who own primarily physical capital. In contrast, such 
an implication cannot be derived in median voter style models in which an increase in capital shares translates into higher incentives for the bulk of voters to support higher levels of redistribution.

Despite significant recent advances in the study of political economy ${ }^{3}$, the literature in this area has until now been overwhelmingly theoretical, providing us with alternative models of the relationship between economics and politics but with few criteria to help us choose among them. The few recent empirical efforts that exist in this arena are commonly geared towards understanding the implications of particular models and not towards comparatively evaluating theories. ${ }^{4}$ By conducting comparative empirical tests of two of the most popular theories of politics - the median voter theory and the interest groups theory -, our paper contributes to the development of an understanding of the explanatory power of alternative political economy theories.

The rest of the paper is organized as follows: In Section 2 we present our basic framework, which consists of two alternative political economy models - a median voter and an interest groups model - combined with a simple economic model of investment in human capital, and derive the comparative statics implication of a change in the factor distribution of income for each of them. Section 2.3 discusses the role of the endogeneity of political mobilization and factor prices as well as the availability of alternative redistributive mechanisms for our results. In Section 3 we explore in more detail our empirical evidence and argue that our results are not due to choice of specification, influential outliers, or reverse causation. We conclude by sketching the implications of our results for existing debates among alternative views of distributive politics.

\footnotetext{
${ }^{3}$ See Drazen (2000) and Persson and Tabellini (2000) for recent surveys of this literature

${ }^{4}$ Some recent examples are Krussell and Rios-Rull (1999) and Goldberg and Maggi (1999).
} 


\section{Two Political Economy Models of investment in human capital}

In this section we provide a simple stylized description of an economy with heterogeneity in the distribution of human and physical capital and examine the ability of two alternative political economy assumptions to account for the observed correlation between capital shares and public investments in human capital. We show that, within the framework of our economic model, the median voter hypothesis is unable to account for the observed relationship between government spending and capital shares, as it predicts a positive relationship between investment in human capital and factor shares. This prediction can be reversed if we assume that the median voter owns significant amounts of capital. However, such an assumption is empirically hard to justify. In contrast, an interest groups model can naturally explain the observed correlations.

\subsection{A Median Voter Model}

We illustrate the problems the median voter hypothesis has in justifying the capital share - investment in human capital correlation with a simple model of an economy with a linear production technology and marginal products $w$ and $r$ for human $(H)$ and physical $(K)$ capital ${ }^{5}$. The model we present is similar to Meltzer and Richard 's (1981) model of voting over redistribution, except that in our model taxes are redistributed via public investment in education and not through a lump-sum transfer. We specialize to a static setting in order to concentrate on the distributive aspects of investment in human capital and not on its intergenerational dimension. We will have two types of agents in this economy: workers, who own only labor, and capitalists, who own labor and capital. Workers comprise more than half of the population, making a worker the decisive - or median - voter. Letting $y_{i}$ stand for the pre-tax income of individual $i$, where $i=h$ denotes workers (who own only human capital) and

\footnotetext{
${ }^{5}$ The assumption of constant marginal products is relaxed in section 2.3
} 
$i=k$ denotes capitalists (who own both human and physical capital), we can write:

$$
\begin{gathered}
y_{h}=w H \\
y_{k}=w H+r K
\end{gathered}
$$

with total factor income being:

$$
n_{h} y_{h}+n_{k} y_{k}=n_{h} w H+n_{k} w H+n_{k} r K
$$

where $n_{i}$ denotes the number of agents of type $i$. Normalizing $n_{h}+n_{k}=1$, this becomes:

$$
w H+n_{k} r K
$$

Taxes are levied on capital owners to finance the accumulation of human capital $^{6}$. We assume that taxes collected equal $\tau n_{k} r K$ minus collection costs $D\left(n_{k} r K, \tau\right)$. We use a simple functional form $D(x, \tau)=\kappa x \tau^{2}$ for the costs of collecting taxes at a rate of $\tau$ on a tax base $x$. This simple functional form embodies the assumption that collection costs are proportional to the deadweight losses from capital taxation, which are quadratic in the tax rate. ${ }^{7}$ The balanced budget constraint specifies that:

$$
H=n_{k} r K\left(\tau-\kappa \tau^{2}\right)
$$

\section{After-tax incomes are:}

\footnotetext{
${ }^{6}$ Whether most public education actually raises productivity and growth is a matter of controversy, as pointed out in fn.1. However, our model only requires that it raise the income of the beneficiaries. Pritchett (1996) and Easterly (2001), two of the main scholars who dissent from the view that public education raises productivity, present stories in which it raises private incomes (through rent-seeking) but not national income. Their interpretation would thus be consistent with our theory.

${ }^{7}$ The result that deadweight losses will be quadratic in the tax rate is originally due to Samuelson (1964). See Also Atkinson and Stiglitz (1980, p. 367-370).
} 


$$
\begin{aligned}
& y_{h}=w H \\
& y_{k}=w H+r K(1-\tau)
\end{aligned}
$$

As workers make up more than half the population, the decisive (or median) voter is a worker. Thus the voting equilibrium in a well-functioning democracy is given by the tax rate that maximizes:

$$
y_{h}=w H=w n_{k} r K\left(\tau-\kappa \tau^{2}\right)
$$

which is simply:

$$
\tau=\frac{1}{2 \kappa}
$$

Substituting this value in (1) allows us to establish that:

$$
\frac{d h}{d \alpha}>0
$$

where $h=\frac{n_{k} r K\left(\tau-\kappa \tau^{2}\right)}{w H+n_{k} r K}$ is the ratio of investment in human capital to total factor income. The intuition for this result is quite simple - as investment in human capital is financed with taxes on physical capital, a higher capital share implies a higher availability of resources to finance investment in human capital. This intuition carries over in a very straightforward manner to more general specifications of the tax schedule: as long as workers can make capitalists pay for part of the cost of acquiring human capital, then a higher share of resources in the hands of capitalists means that the cost to workers of accumulating higher levels of human capital is smaller, leading them to vote for higher levels of h. Equation (6) makes it hard to reconcile a median voter model with the correlations between capital shares and investment in human capital described in Sections 1 and 3 . 


\subsubsection{Ownership of Capital by the Decisive Voter}

One way to temper this result is by introducing ownership of capital by the median voter into our model. In that case she would set $\tau$ to maximize

$$
w H+\pi n_{k} r K(1-\tau)
$$

where $\pi$ is the fraction of capital held by the median voter. Maximizing with respect to $\tau$ and substituting the solution back into the definition of $h$ gives:

$$
h=(1-\pi) \alpha \frac{1}{\kappa}\left(\frac{1}{4}-\frac{1}{4 p(\alpha)^{2}}\left(\frac{\pi}{1-\pi}\right)^{2}\right)
$$

where $p(\alpha)=w$ is the inverse function of $\alpha$, which can be shown to have $p^{\prime}(\alpha)<0$ everywhere. The derivative of (8) with respect to $\alpha$ has an indeterminate sign. The higher the amounts of capital owned by the median voter, the less likely it is that an increase in the capital share will lead her to raise the tax on capital. Given a sufficiently high level of $\pi$, the negative correlation between capital shares and investment in human capital can be justified with a median voter hypothesis.

Is it reasonable to assume that the median voter owns a substantial amount of capital? Although we lack systematic data on wealth ownership for a large number of countries, the data that exists suggests that median levels of wealth are extremely low. In the United States, for example, $84 \%$ of net worth and $93 \%$ of financial wealth is held by the top quintile of the wealth distribution. Only $4.7 \%$ of net worth and $0.1 \%$ of financial wealth belongs to the lowest three quintiles [Wolff,1998]. These numbers are slightly higher - but still low - for other developed economies. ${ }^{8}$ Regrettably, data on wealth distribution is scarce for developing countries, but what there is - along with simple casual observation - indicates that it is much more unequal. For example, the gross capital income of the poorest $60 \%$ of the Venezuelan population is only 2.2 $\%$ of total gross capital income. ${ }^{9}$ Given that this number is gross of debt,

\footnotetext{
${ }^{8} 11 \%$ of French and $7 \%$ of Australian Net Worth is in the hands of the three lower quintiles
} of these countries' wealth distribution (Wolff, 1996).

${ }^{9}$ Rodríguez (2004). 
it is possible that the net capital income of the median voter in this case is actually negative! Furthermore, there is systematic data for a large number of developing countries showing that inequality in the ownership of at least one important asset - land - is markedly higher in developing countries than in developed countries. ${ }^{10}$ Taken together, the facts that the distribution of income is systematically more unequal and that credit markets are substantially less developed in poor countries suggest that the distribution of capital must be more unequal than in rich countries. The bottom line is that in the overwhelming majority of countries the proportion of wealth in hands of the majority of the population is negligible, which makes it highly likely that $\pi$ is very near zero (or even negative) and $\frac{d h}{d \alpha}$ is positive.

In countries with a restricted franchise, the level of wealth of the decisive voter could be significantly different from that of the median adult individual. In such cases, it may not be unreasonable to assume that the decisive voter's $\pi$ is large enough to induce a negative correlation between investment in human capital and capital shares, allowing this modified version of the median voter model to explain the observed pattern in the data. An example of this type of reasoning is in Wacziarg (2001), who argues that non-democratic polities can be modelled as systems in which the decisive voter belongs to the upper tail of the wealth distribution. An implication of such a view is that the link between capital shares and investment in human capital should be weaker in democracies. We will explore this hypothesis in section 3 below. However, it must be noted that such a view implies accepting a significant deviation from the model of democratic politics implicit in median voter theory.

\footnotetext{
${ }^{10}$ Deininger and Squire (1998) report Gini indices based on the distribution of operational holdings of agricultural land assembled from the Decennial FAO World Census of Agriculture. They show that on average Gini coefficients in the distribution of land are higher in developing countries than in developed countries.
} 


\subsubsection{Endogeneity}

The derivation of equation (6) also brought out the fact that the correlation between $\alpha$ and $h$ discussed in Section 1 is, in the framework of our model, a correlation between two endogenous variables. Therefore, in principle it would be desirable to estimate the system of equations given by $h(\alpha)$ and $\alpha(w, r)$. In practice, most of our discussion will center on the relationship between $\alpha$ and $h$. We do this both because cross-country comparable data on $w$ and $r$ is impossible to find for the broad cross-section of countries that we want to study, and because an alternative rewriting of our model (discussed in section 2.3 and developed in detail in the working paper version) in which the capital share is exogenous delivers similar results. However, it is important to bear in mind the fact that $\alpha$ is an endogenous variable, an issue that we will adress in depth in Section 3, where we estimate $h(\alpha)$ using instrumental variables.

\subsection{Equilibrium with Interest Groups}

As we discussed above, the median voter hypothesis cannot - within the framework of our simple model - give us a satisfactory explanation for the negative correlation between capital shares and public investment in human capital. As we now show, such a correlation can be accounted for with a simple model of interest groups and political influence. In the model we present, organized groups of capitalists and workers bargain with politicians over existing policies. We model politically organized groups as capable of offering money contributions to politicians in exchange for policies that are favorable to their interests. The politician evaluates offers of money transfers from capitalists and workers before setting a policy, also taking into account the cost that deviating from the median voter's preferred policy will have for him. The interaction between interest groups and the policymaker is evaluated using the theory of common $\operatorname{agency}^{11}$.

The structure of the game is simple: organized group $i$ will propose a con-

\footnotetext{
${ }^{11}$ See Bernheim and Whinston (1986) and Dixit, Grossman and Helpman (1996).
} 
tribution schedule $C_{i}(\tau)$ to the policymaker, where the contribution that the policymaker will receive will be conditional on her choice of tax rate $\tau$ (with the implied choice of $H$ determined from the government budget constraint). Workers and capitalists set the contribution schedules to maximize their posttax incomes or consumption levels, which are respectively:

$$
\begin{gathered}
d_{h}=w H-C_{h}(\tau), \\
d_{k}=w H+r K(1-\tau)-C_{k}(\tau) .
\end{gathered}
$$

The policymaker is assumed to care about the welfare of workers (the decisive voter) as well as the total amount of campaign contributions that she receives:

$$
U_{p}=w H+\lambda C
$$

for $C=n_{h} C_{h}+n_{k} C_{k}$. Equation (11) therefore assumes that the elected policymaker cannot maximize the utility of voters: in order to stay in power she must set policies to maximize a linear combination of the decisive voters' utility and the sum of political contributions. This behavior could either represent the needs of the policymakers for a certain amount of resources to stay in power or the fact that the average policymaker will to some degree be "corrupted" by bribes.

Whether appropriate microfoundations can be established for a function such as (11) is a matter that has captured a considerable deal of attention in the literature. Grossman and Helpman (1996) have derived such a function from a model in which politicians jockey for support of informed and uninformed voters, while Rodríguez (1998) has shown that it will characterize equilibrium policies in the context of a game in which politicians compete for the suport of voters who are informed but uncertain about the underlying effeciveness of the candidates as policymakers. Besley and Coate (2001) analyze the implications 
of using this setup vis-a-vis a model of citizen candidates to study the effect of lobbying.

This game has the structure of a common agency game as studied by Bernheim and Whinston (1986). Bernheim and Whinston show:

Proposition 1 A Subgame Perfect Nash Equilibria $\left\{C_{i}^{*}\left(\tau^{*}\right), \tau^{*}\right\}$ of a common agency game with quasi-linear utilities will be characterized by the following four conditions:(i) $C_{i}^{*}\left(\tau^{*}\right)$ is feasible; (ii) $\tau^{*}$ maximizes the policymaker's utility $U_{p}$ given the contribution schedules; (iii) For each lobby $i, \tau^{*}$ maximizes the weighted sum of the welfares of the government and that group $\frac{w H}{\lambda}+C+d_{i}$; (iv) For each lobby i, $U_{p}^{*}=w H\left(\tau^{*}\right)+\lambda C\left(\tau^{*}\right)=w H\left(\tau^{-i}\right)+\lambda\left[C_{j}\left(\tau^{-i}\right)\right]$ where $j \in\{h, k\}, j \neq i$ and $\tau^{-i}$ is the tax rate that maximizes the policymaker's utility function when $C_{i}=0$.

Conditions (ii) and (iii) jointly imply that:

$$
\left.\frac{d}{d \tau}\left\{w H(\tau)+\lambda\left\{w H(\tau)+n_{k} r K(1-\tau)\right)\right\}\right\}=0 .
$$

Government policies are chosen as if to maximize a weighted average of voters' utility function and that of organized lobbies. Although we have derived (12) from the microfoundations of the common agency model, it can also be derived from a number of models with the property that policies are on the contract curve between governments and lobbies. ${ }^{12}$ Substituting (1) into (12) and reorganizing we get:

$$
\frac{d}{d \tau}\left\{w n_{k} r K\left(\tau-\kappa \tau^{2}\right)(1+\lambda)+\lambda n_{k} r K(1-\tau)\right\}=0 .
$$

This condition implies that $\tau^{*}=\frac{1}{2 \kappa}-\frac{1}{2 \kappa w} \frac{\lambda}{1+\lambda}$. Substituting this value back into $h$ we get:

$$
h=\frac{\alpha}{\kappa}\left(\frac{1}{4}-\frac{1}{4}\left(\frac{\lambda}{1+\lambda}\right)^{2} \frac{1}{w^{2}}\right)
$$

\footnotetext{
${ }^{12}$ See Zusman (1976), Hillman (1989), and Scarpa (1994) for examples.
} 
where $w=p(\alpha)$ is the inverse function of $\alpha$, which can be shown to have $p^{\prime}<0$ everywhere. Taking derivatives with respect to $\alpha$ gives us:

$$
\frac{d h}{d \alpha}=\frac{h}{\alpha}-\frac{1}{\alpha w} \frac{2\left(\frac{\lambda}{1+\lambda}\right)^{2} \frac{1}{w^{2}}}{1+\left(\frac{\lambda}{1+\lambda}\right)^{2} \frac{1}{w^{2}}} \gtrless 0 .
$$

Note that as $\frac{\lambda}{1+\lambda} \frac{1}{w}$ tends from below to $1, \frac{d h}{d \alpha}$ becomes negative ${ }^{13}$. In other words, when the wage rate is sufficiently small (so that capitalists do not care much about their labor income) or when the political power of money is large (high $\lambda$ ), increases in capital's share will lead to a reduction in spending on human capital accumulation. ${ }^{14}$ The reason is simple: a higher $\alpha$, by concentrating a greater proportion of income in the hands of capitalists, gives them greater power to use that income in order to affect the policies carried out by politicians. That is, it raises the purchasing power of capitalists. As capitalists desire a lower level of human capital than workers they will use that enhanced political power to pressure for lower spending in $h$.

Another way of looking at this derivative is by expressing (14) as:

$$
\frac{d h}{d \alpha}=\frac{\tau^{*}-\kappa \tau^{* 2}}{n_{k}}+\frac{1-2 \kappa \tau^{*}}{n_{k}} \alpha \frac{\partial \tau}{\partial \alpha} .
$$

The first term on the right-hand side of (15) is positive and reflects the fact that, at any given tax rate, a higher capital share implies that there are more resources to finance human capital investment through taxation, raising the median voter's incentive to attempt to extract these resources. We call this the income effect. It captures the fact that as capital's share goes up, there should be more investment in human capital. It was the only term present

\footnotetext{
${ }^{13}$ Strictly speaking, (14) is not a comparative statics result, as $\alpha$ is an endogenous variable and not an exogenous parameter of the system. It is best viewed as a partial derivative along one equation of the structural form of a system formed by (13) and $\alpha=p^{-1}(w)$. We prefer this specification for the purposes of empirical estimation because of lack of availability of systematic cross-country data on $w, \lambda$, and $\kappa$. See however our further comments in Section 3.

${ }^{14}$ If $\frac{\lambda}{1+\lambda} \frac{1}{w}>1$, then the wage rate is sufficiently small and the political influence of money is so high as to induce a tax rate of zero (which of course implies $\frac{d h}{d \alpha}=0$ ).
} 
in the median voter model and generated that model's problematic implication for the relation between investment in human capital and the capital share. As we pointed out in our discussion of the median voter model, this effect is present as long as workers can make capitalists pay for part of the cost of human capital accumulation; in those cases a higher share of resources in the hands of capitalists means that the cost to workers of acquiring higher levels of human capital is smaller.

The second term - which we call the political power effect - represents a countervailing factor that appears in the interest groups model and reflects how the higher capital share alters the distribution of political power. Formally, it comes form the fact that condition (iii) of Proposition 1 implies that the government must maximize a weighted average of its welfare and that of each interest group taken separately. An increase in a group's share of income implies an increase in the weight that group has in this maximization exercise. Simply put, in an interest groups model your importance will be proportionate to the amount of resources that you have, because these will determine your capacity to pay for policies.

\subsection{Extensions}

The above model is intentionally simple. It assumes that the changes in the functional distribution of income have no effect on the degree of political mobilization, an important determinant of the capacity to lobby. It also assumes fixed and exogenous factor prices, ruling out any indirect effect that investment in human capital can have on the well-being of different groups through factor prices. Furthermore, in our model there is no possibility of redistribution via other means than spending on human capital. In this section we show how our model can be extended to take into account these complexities. A more detailed exposition of these results can be found in the working paper version. 


\subsubsection{Endogenous Political Mobilization}

Changes in factor shares imply changes in the incentives that individuals have to organize politically and therefore should affect the distribution of political power. Understanding how changes in capital shares affect incentives for political mobilization would be a necessary part of a complete theory of how money affects politics. We can model political mobilization in a simple tractable way by assuming that each group must pay a cost $\gamma_{i}$ in order to organize politically, and that only politically organized groups can give money contributions. The pair of organizational decisions will induce a political equilibrium $\tau^{*}$ and $H^{*}$. Given the payoffs induced by these political equilibria, groups will decide whether to organize or not, and we can look for a Nash equilibrium in the game of political mobilization. This model can be solved under the additional assumption that contribution schedules are globally truthful, that is, that whenever the contribution is non-zero its first derivative with respect to the vector of policies must be the same as that of the agent's utility function 15. The equilibrium may display political mobilization of one, both or none of the groups (there is also the possibility of mixed strategy equilibria). In the working paper version of this paper, we prove that the equilibrium with no political mobilization always corresponds to a sufficiently low capital share, whereas the equilibrium with full political mobilization always corresponds to a sufficiently high capital share. Given that with full political mobilization the tax rate is lower than with no political mobilization, then it is true that if one compares income distributions that are very skewed towards capitalists with those that are very skewed towards workers one will always find greater tax rates in the latter, confirming the main thrust of our hypothesis. However, this is not necessarily true when one compares more intermediate ranges of the factor distribution of income For these intermediate income distributions, the effect of factor prices on the incentives for political mobilization are ambiguous and depend very much on the levels of exogenous parameters.

\footnotetext{
${ }^{15}$ See Bernheim and Whinston $(1986,1987)$ and Bernheim, Peleg and Whinston (1987).
} 


\subsubsection{Endogenous Factor Prices}

Although convenient analytically and for purposes of exposition, the assumption of exogenous factor prices is unrealistic. Government policies can and often do affect domestic factor prices, and governments usually place importance on the redistributive effects of induced factor price changes. How does dealing with the endogeneity of factor prices affect our results?

When factor prices are endogenous, it is not always true that labor prefers higher levels of investment in human capital, nor that capitalists always oppose it. Policies to increase the level of human capital push down the marginal product and therefore the wage of human capital while pushing up the marginal product and thus the return to physical capital. Whether these changes in factor prices will be strong enough to change groups' preferences over policies will depend on how substitutable human and physical capital are. For high levels of substitutability, factor returns are not much affected by $H$ and the intuition of the model in the previous sections is maintained. But if substitutability between $H$ and $K$ is low, capitalists may actually prefer higher levels of investment in human capital than workers. In the working paper version we show that the opposition of interests between the owners of physical capital and the owners of labor that is the backbone of our model will hold as long as the elasticity of substitution is higher than $\alpha$. Note that this implies that for the Cobb-Douglas case, where the elasticity of substitution is 1 and factor shares are exogenous, our results will hold except in the knife-edge case where $\alpha=1$.

According to our data, the average value for $\alpha$ is .53 , and a full $80 \%$ of the sample corresponds to $\alpha<.66$. The average value of the capital share can be much lower - between .35 and .45 - if one attributes a portion of the income from unincorporated enterprises (counted as capital income in national accounts) to labor. It therefore appears that we would need elasticities of substitution that are closer to zero than to one in order for workers to prefer lower levels of investment in human capital than capitalists in the bulk of our sample. However, empirical work on the elasticity of substitution between 
capital and labor indicates that $\sigma$ is unlikely to be substantially smaller than 1. ${ }^{16}$ Therefore, although the case in which capitalists desire higher $H$ than workers is definitely of theoretical interest, it does not appear to be empirically very relevant.

\subsubsection{Alternative Redistributive Mechanisms}

The presence of alternative mechanisms of redistribution may modify our story. If there is an exogenous decrease in the wage rate (and consequently a fall in the capital share ) and these alternative mechanisms are in place even governments that respond to the wishes of the median voter will react by shifting some resources from investment in human capital to the other means of redistribution. This can cause investment in human capital to fall in response to increases in capital shares.

We would like to make two points about this alternative explanation. The first one is that there are a number of good reasons why it may be sensible to assume - as we do - that investment in human capital is the only way in which resources can be transferred from rich to poor individuals. More sophisticated instruments of redistribution - such as a progressive system of taxation and a well-developed welfare state - are either inexistent or insignificant in many developing countries. The difficulties associated with monitoring a system of progressive income taxation are vast and require a level of administrative sophistication and institutional capacity which many developing countries have not attained $^{17}$. Furthermore, alternative means of redistribution - such as price

\footnotetext{
${ }^{16}$ Betancourt and Clague (1981) provide microeconomic evidence consistent with this hypothesis: they estimate $\sigma$ using UNIDO data for 17 industries and derive an average estimate of .917. Rowthorn (1999) argues that lower values of $\sigma$ are plausible, but recognizes that "the economy-wide elasticity of substitution is greater than that suggested by disaggregated studies " since at the economy-wide level consumers substitute between industries.

${ }^{17}$ The skewness of the distribution of the percentage of revenues arising from taxes on income and profits is positive and significant (p-value for rejection of normality is 0.000), while for taxes on goods and services it is not ( $\mathrm{p}$-value for rejection of normality $=0.212$ ), suggesting that there are many countries that have substantial problems in developing progressive systems of
} 
controls, subsidies to consumption or production of basic commodities or direct provision - are often highly inefficient. It is not a coincidence that economists advising developing countries generally recommend a focus on investments in education and health as the optimal mechanisms for reducing poverty and inequality.

Our second point is that a shift towards this explanation does not solve the problems of the median voter model in accounting for the patterns present in the data. Although it can explain a negative correlation between investment in human capital and capital shares it also implies that as capital shares increase we should see countries shifting their composition of spending towards redistributive transfers and away from investment in human capital, something that does not occur in the data. This result is formally established in the working paper version of this paper, and in Section 3 we show that non-human capital related redistributive transfers display a negative relation with capital shares that is as strong as that of investment in human capital.

\section{Empirical Evidence}

We now test the comparative implications of our models with a panel of data for developing and developed economies from 1960 to 1997 . Our dependent variables will include indicators of investment in human capital, government consumption, general government expenditures and government investment. Independent variables include the capital share, the log of per capita GDP and a set of other controls. Capital shares are calculated as the sum of operating surplus and depreciation divided by GDP at factor cost. In order to abstract from business cycle effects, we use five-year averages of all our variables. A detailed description of the data used is in Appendix 2.

taxation. The countries with greater difficulties for collecting income and profits taxes are, not surprisingly, poor countries: a simple regression of taxes on income shows that a doubling

of per capita GDP is associated with an increase of $9 \%$ in the share of revenues coming from income taxes. 


\subsection{Single Equation Estimation}

We center on estimating linearized versions of equation (13), which specifies $h$ as a function of $\alpha$ and a set of exogenous parameters. It is important to note that, in the context of our model, $\alpha$ is an endogenous variable determined by (??). In this subsection, we will concentrate our analysis on single equation estimates of (13), while in the next subsection we address the issue of endogeneity through Granger causality and system methods of estimation. We also estimate analogous equations using indicators of general redistributive spending ( $s$, proxied by government consumption), total expenditures $(g)$ and government investment as dependent variables. Our right hand side variables are for the most part common controls in empirical studies of state expenditures. A long tradition in political science has associated the level of government spending with the level of per capita income - the implicit assumption being that many of the public goods provided by governments are luxuries which can be afforded once basic necessities have been provided. The point was first made by Wagner (1893) although subsequent tests (see Mueller, 1989 and Ram, 1987) have generally failed to find support for the hypothesis. Some authors have pointed to the importance of economies of scale in the provision of public goods and therefore to the need for using an indicator of the absolute size of the economy - such as level of absolute GDP or population - as a regressor (Alesina and Wacziarg, 1998). Spending on redistribution and human capital is often targeted to specific age groups in the population (the young in the case of education and the old in the case of pensions), so that it seems desirable to control for the age composition of the population. We also use a variable measuring the initial stock of human capital to capture the extent of increasing/diminishing returns in the accumulation of human capital. Thus our baseline regressions control for the log of per capita GDP, the log of population, the percentage of the population aged over

65 and under 15, and initial life expectancy (a common measure of the stock of human capital). We explore the sensitivity of our results to changes in this list of controls below. 
Table 1 presents some basic summary statistics for our data. As one can see, there are important differences across countries in our indicators of spending and investment in human capital. Spending on public education ranges from a low of $.5 \%$ to a high of $10.5 \%$ of GDP. A good number of countries (mostly in sub-Saharan Africa) have no social security system, while some OECD countries devote between one-tenth and one-fifth of its GDP to it. General government consumption ranges from $4 \%$ of GDP (Oman, before the oil boom) to over $30 \%$ of GDP (Oman, after the oil boom). These variations are far from only being determined by levels of income or geography: for example, the standard deviation of public education expenditures within sub-Saharan Africa (1.99 percentage points) is higher than the difference between its average spending on education and that of the OECD (1.11 percentage points).

The same assertion applies to the data for capital shares. The variation in capital shares among countries is substantial, going from a low of between .1 and .2 to a high between .8 and .96 , depending on the assumption that is made about the appropriate apportionment of income from unincorporated enterprises to capital's share (an issue which is discussed more in depth below). It does appear that capital shares are systematically related to income: the simple correlation with the log of GDP per capita is -.63. As the last five rows of Table 1 show, capital shares are lowest in OECD economies and highest in Sub-Saharan Africa. Furthermore, it also seems that differences in shares of capital are related to the distribution of income: the simple correlation between capital shares and Gini coefficients is .48 and with intersectoral wage dispersion (a proxy for wage inequality) is $.46 .^{18}$ It also seems that they are related to the political strength of labor: the partial correlation between capital shares and unionization rates is -.52 .

In Table 2 we present some first random effects regressions to systematically analyze the relationship between capital shares and our spending variables. The strong pattern arising from these regressions, as was pointed out in the intro-

\footnotetext{
${ }^{18}$ Gini coefficients are from Deininger and Squire (1996) and wage dispersion is calculated from UNIDO Industrial Statistics.
} 
duction, is that capital's share of GDP seems in most cases to be the single strongest predictor of spending patterns. Capital's share of GDP is negatively associated with spending on public education and public health spending and weakly negatively associated with social security taxes, broadly confirming our story of a correlation between capital shares and investment in human capital. It is also strongly negatively related to government consumption, a commonly used measure of redistribution ${ }^{19}$. The patterns in the composition of these variables are also suggestive: Public spending in health is negatively related to capital shares, but private spending in health is not. This suggests that the reason behind greater public spending on health when capital shares are low is not simply the greater efficiency of investing in $h$ (which should also affect private health spending) but the change that low capital shares induce in the distribution of political power. Likewise, when capital shares rise spending on primary education falls the most; spending on secondary education seems unaffected and spending on higher education actually rises, suggesting that the effect of capital shares on investment in human capital is strongest when there is a greater redistributive component to $h$. However, government investment is unrelated to capital shares - again something that would be suggested by its lack of use as a redistributive tool ${ }^{20}$. The fact that total government spending is the sum of government consumption and capital expenditures implies that total government spending is also negatively related to capital shares, again in contrast to the prediction of the median voter model. In sum, our results are broadly supportive of the interest groups model and contradict the implications

\footnotetext{
${ }^{19}$ The definition of general government consumption used $\mathrm{f}$ includes all current spending for purchases of goods and services (including wages and salaries) by all levels of government, excluding most government enterprises. It also includes most expenditures on national defense and security. This is the tradtional definition of government consumption, as in for example World Bank (1999). An alternative definition of government consumption, commonly used in growth studies, excludes expenditure on education and national defense and security from the traditional definition. Our results still hold when we use that more restrictive definition. ${ }^{20}$ A similar point is made by Alesina (1997), who discusses the lack of use of public investment as a redistributive tool in the context of fiscal adjustments.
} 
that arise from the median voter model.

As a number of results in the literature vary widely with the specification of the estimated equation and given that equation (13) is a highly non-linear function, we turn now to exploring the possibility of specification bias in our regressions. The first row of Table 3 reproduces our estimate of the coefficient on capital shares from our baseline specification of Table 2 . In the second row we show the results of estimating our system under a specification with fixed country-specific effects, as would be appropriate if the country-specific effects are correlated with the regressors - as they most likely are. Despite the sacrifice in data entailed by dropping all the cross-sectional information, all variables that were significant under the random effects specification remain significant under fixed effects - with the statistical significance of the coefficients on public spending on education and total expenditures weakened but that of social security spending strengthened. In the next two rows we explore sensitivity to functional form. First we show in row 3 the estimates when both the right hand side and left hand side variables are expressed logarithmically, as suggested by Rodrik (1998). Row 4 uses the alternative functional form for redistribution in median voter models that arises out of the classical median voter model of redistribution of Meltzer and Richard (1983), in which the log of the tax rate is a function of the inverse of $\mathrm{GDP}^{21}$. The next row turns to the issue of outliers: in order to make sure that our results are not driven by highly influential observations, we exclude all of these observations as measured by the dfbeta indicator (Besley, Kuh and Welsch, 1980). ${ }^{22}$ dfbeta measures to what

\footnotetext{
${ }^{21}$ See Meltzer and Richard (1983) for a derivation. Rodriguez (1998) also derives this functional form in the context of an interest groups model of redistribution.

${ }^{22}$ That is,

$$
\text { dfbet } a=\frac{r_{i} u_{i}}{\sqrt{U^{2}\left(1-h_{i}\right)}}
$$

where $r_{i}$ is the studentized residual of the regression, $u_{i}$ is the residual obtained from a regression of the explanatory variable of interest on other explanatory variables, $U=\sum_{i} u_{i}^{2}$ and $h_{i}$ is the leverage of observation $i$.
} 
extent the coefficient on capital shares changes when the $j-t h$ observation is excluded from estimation. We follow the suggestion of Besley, Kuh and Welsch (1980, p.28) to reestimate the equations excluding all the observations in which dfbeta, scaled by the estimated standard error of the coefficient, is greater than $\frac{2}{\sqrt{n}}$.

Our capital shares are based on the standard national accounts definition of operating surplus, which includes all income from unincorporated enterprises (self-employment). Therefore our capital shares count as income from capital the part of the income of self-employed individuals that should be attributed to labor, overestimating capital's contribution to GDP. The next three rows of Table 3 (rows 6-8) explore the sensitivity of our results to this assumption. In them we report the results of regressions where the indicator of the capital share has been adjusted to attribute all (row 6), 2/3 (row 7) or 1/3 (row 8) of the income from unincorporated enterprises to labor. ${ }^{23}$ Row 8 shows the results of reestimating capital shares excluding depreciation from capital's income. ${ }^{24}$ In a recent paper, Gollin (2002) has suggested estimating capital shares by apportioning to workers the same fraction of income from unincorporated enterprises as they earn in the rest of the economy. Regrettably, this method can only be applied to a subset of primarily developed economies. In our case, this implies reducing the number of countries in the sample from 69 to 19 , so it is not surprising to find that the results are considerably weakened (row 9). However, row 10 shows that if we estimate the regression with our baseline indicator in the same restricted sample, the results do not differ significantly from those using

\footnotetext{
${ }^{23}$ This is a common adjustment. See for example Krueger (1999). When data on income from unincorporated enterprises was unavailable, we estimated it by using the coefficients from a regression of it on per capita GDP.

${ }^{24}$ Conventional estimates of capital's share (see for example Jorgenson and Grillichees, 1972) include depreciation as part of capital income under the justification that in a competitive equilibrium the marginal product of capital should be sufficient to cover both the return to capital and the replacement of depreciated capital $\left(f^{\prime}=r+\delta\right)$. However income net of depreciation may be a better measure of capital's bargaining power. We thank Samuel Bowles for bringing this issue to our attention.
} 
the Gollin data. In only two out of the eight regressions is there a statistically significant difference in the coefficients, and in only one out of them do the signs differ.

In Table 4 we turn to the issue of sensitivity to alternative controls. Rodrik (1998) has suggested that open economies devote more resources to social insurance, and Wacziarg (2001) has argued that democracies have higher rates of investment in human capital. In Table 4 we show that our results are not sensitive to controlling for these variables. Consistent with Rodrik's hypothesis, total government spending and government investment are positively related to openness, although some of the other variables are not. The hypothesis of a link between investment in human capital and democracy is not confirmed by our evidence: the coefficient on the political rights and civil liberties variables are not statistically significant in any systematic way after capital shares are controlled for. A possible reason for this is that, unlike us, Wacziarg uses indicators of enrollment rates as his dependent variable. In contrast, our dependent variables measure the resources invested in human capital. ${ }^{25}$ The last column of Table 4 shows an additional robustness test - using mean years of schooling in addition to life expectancy as a measure of the stock of human capital. Our results are again unaffected by this addition. In what follows, we omit these variables from our specification because they tend to significantly reduce our degrees of freedom.

As pointed out in section 2.1.1, a modified version of the median voter hypothesis could attempt to explain the negative correlation between capital shares and investment in human capital as a result of the fact that in systems where the franchise is restricted the decisive voter could be much wealthier than the median adult individual. One implication of this hypothesis is that as the franchise becomes less restricted, the effect of capital shares on investment in human capital should be smaller. In Table 5 we test for the existence of an

\footnotetext{
${ }^{25}$ Wacziarg's results could be due to the fact that freer and more democratic societies are more efficient at converting a given amount of resources into higher enrollment rates - not that they actually devote more resources to human capital accumulation.
} 
interaction between the level of democracy (an indicator of the extent to which restrictions on the franchise can be sustained) and capital shares. We present two specifications of the interaction: a linear one (the product of capital shares and the democracy index) and a discrete one (the product of the capital share with a dummy that equals one when the democracy index exceeds the sample average). In only one of the sixteen regressions is there a significant interaction term (at 10\%), and it has the opposite sign from what the modified median voter theory would predict.

We have also suggested that the absence of a correlation between expenditure per student on secondary and higher education and capital shares is due to the fact that spending on non-primary schooling does not necessarily have redistributive effects. Investment in secondary and higher education in very poor countries is likely to benefit only urban elites; only in advanced economies will it benefit the poorer sectors of the population. If our explanation is correct, we would expect that as economies become richer and the average level of education of the economy improves, investment in secondary and higher schooling will start to take on a redistributive nature and the effect of capital shares on educational expenditures will become strongly negative. The results in Table 6 confirm this: an interaction term between the level of GDP per capita and the capital share is strongly negative, indicating that as incomes per capita rise the effect of capital shares on spending on all levels of education goes from being positive to being strongly negative. The level of per capita GDP at which the effect of the capital share on education spending becomes negative is smallest for primary schooling (129 US\$), higher for secondary schooling (1510 US\$) and highest for higher education (9750 US\$). None of our 867 observations correspond to countries that were below the lower threshold for primary schooling. Spending on secondary schooling would appear to be redistributive for the richest $59.8 \%$ of economies in the sample, while spending on higher education is redistributive only for the richest $10.6 \%$ of economies in the sample. According to our estimates, spending on secondary schooling becomes progressive when an economy surpasses a level of income roughly equal to that of Bolivia at the 
presentm whereas spending on higher education becomes progressive when an economy attains the level of income now held by Singapore.

\subsection{Reverse Causation}

An alternative explanation for our results is that they are due not to the effect of capital shares on investment in human capital but rather to the effect that investment in human capital has on capital shares. Higher spending on human capital could lead to higher stocks of human capital and lower shares of income in physical capital. ${ }^{26}$ We do not deny that such a link is part of the story. Indeed, our theoretical model of Section 2 explicitly recognizes the endogeneity of capital shares. As we point out there, estimation of our model should take into account the fact that capital shares are an endogenous variable which is affected by changes in factor prices ${ }^{27}$. In this section we reestimate our model taking into account this possible endogeneity and show that the source of our correlation cannot be attributed to reverse causation but rather appears to come from the effect of capital shares on government spending.

We do this in two ways. First, we perform Granger causality tests on the relationship between the spending variables and investment in human capital. ${ }^{28}$ The results of these tests are in Tables 7.1 and 7.2. The results show that in all five cases studied (lack of sufficient time variation in the data made it impossible to carry out these tests for public spending on health) capital shares Granger cause the spending variables. In three of the five cases (public spending on education, social security taxes and total public spending) capital shares are

\footnotetext{
${ }^{26}$ Note that this is strictly true only if the elasticity of substitution between capital and labor is greater than one. If it is smaller than one, then investment in human capital accumulation would cause higher capital shares.

${ }^{27}$ This problem is of course ameliorated if the economy is closed and the elasticity of substitution between capital and labor is unity (see Section 2.3. In that case, capital shares become a parameter of the system that can only be affected by policies if they change the form of the production function.

${ }^{28}$ Because of data limitations, we use just one (five-year average) lag of the dependent variable in our specifications.
} 
not Granger caused by the spending variables. And even though in two of the remaining cases (spending on primary schooling and government consumption) capital shares are Granger caused by the spending variables, the coefficient on the spending variable in both these cases is actually positive not negative. We conclude that in none of the five cases studied can the negative correlation between capital shares and spending be attributed to reverse Granger causation. ${ }^{29}$

The second way we can address the issue of endogeneity is by estimating the equation for the capital share as a function of wages and the returns to capital. This poses two problems. First, in the real world wages and returns to capital are unlikely to be completely exogenous, as we have postulated in our model. As a matter of fact, the real world probably lies somewhere between the model with endogenous factor returns discussed in section 2.2 and the model with exogenous factor shares of section 2.3. Both factor returns and factor shares are likely to be influenced by economic policies. Second, even if we were willing to treat factor returns as exogenous, data on wages and returns to capital are scant, making estimation of the capital share equation difficult in practice.

However, neoclassical trade theory suggests a natural solution for this problem. According to the Stolper-Samuelson theorem, there should be a relationship in equilibrium between factor returns and a country's terms of trade. ${ }^{30}$ In relatively labor abundant economies, positive shocks to the terms of trade will

\footnotetext{
${ }^{29}$ It is well known that coefficient estimates in panel regressions with lagged dependent variables suffer from simultaneity bias. In the case of our coefficient of interest (that on the lagged right-hand side variable) this bias is towards zero; it therefore makes rejecting the null of no Granger causation even more difficult (see Doel, 1994). We have reestimated the regressions of Tables 6.1 and 6.2 using the Anderson-Hsiao and Arellano-Bond methods for correcting the bias in the lagged dependent variable's coefficient. These methods entail a substantial sacrifice of information because they require both first-differencing and elimination of all information that does not form part of chains of three consecutive observations. As a result, the standard errors in these tests rise substantially, with the result that they are generally inconclusive with respect to the question of causality. However, they do not support the hypothesis that spending Granger causes capital shares.

${ }^{30}$ See Stolper and Samuelson (1941). Contemporary expositions can be found in Bhagwati, Srinivasan and Panagariya (1998) and Dixit and Norman (1980).
} 
cause increases in the wage rate and decreases in the real return to capital. In relatively capital abundant economies, the opposite should happen: increases in the terms of trade should cause increases in the return to capital and decreases in the wage rate. Therefore changes in the terms of trade should be correlated with changes in factor shares. Unless countries are large, their terms of trade should be exogenous to the level and composition of their government's spending. Therefore a natural instrument for the capital share would be an interaction between a measure of the country's capital abundance vis-a-vis the rest of the world and shocks to the terms of trade:

$$
\operatorname{TOTK}_{t}=\left(\operatorname{TOT}_{t}-\operatorname{TOT}_{t-1}\right) *\left(L G D P_{t} / \overline{L G D P}_{t}\right)
$$

where $T O T_{t}$ denotes the level of the terms of trade, $L G D P$ refers to the log of per capita GDP - our measure of a country's capital abundance -, overbar denotes a world average and $t$ is a time sub-index. Countries with positive TOTKI have either experienced a positive terms of trade shock and are capital abundant or have experienced a negative terms of trade shock and are labor abundant. In both cases capital shares should rise. A similar reasoning leads to the conclusion that negative values of TOTKI should be associated with falls in the capital share. As terms of trade shocks can be reasonably said to be exogenous in a sample of predominantly small economies and the log of per capita GDP is already introduced as an alternative explanatory variable in our regressions, TOTKI should be uncorrelated with the residual from our equation.

One drawback of this approach is that trade theory tells us that TOTKI should be correlated with changes in capital shares but not with their level. Indeed, given that TOTKI is simply a ratio of price indices, it is unclear that its level has any economic meaning. Therefore estimation by instrumental variables techniques requires that we first-difference our data, running the danger of losing great part of our source of variation.

We show these results in Table 8 . Column 1 reproduces our baseline esti- 
mation, whereas column 2 shows the results of estimation in first differences. Although the statistical significance of the relation is weakened, capital shares are still negatively related to the spending variables. The third and fourth columns of Table 8 show the results of estimating our equations using three alternative instrumental variables techniques. The first one is simple 2SLS; the second and third are respectively 3SLS and GMM system estimation, with one equation corresponding to each time period (which are necessary because firstdifferencing causes the residuals to be correlated over time). Regrettably, we cannot estimate the public health equation with either method because of lack of observations, nor can we estimate the education spending equation with 3SLS. However, the pattern that emerges from the estimated equations is encouraging. All coefficients have the correct sign and in five out of nine cases, they are statistically significant (two of these at 10\%). Table 9 shows that TOTKI is indeed a strong instrument, with its t-statistic in the first stage regression between 2.05 and 2.22. Although it is apparent that significant information has been sacrificed in order to carry out IV estimation, the results from it remain consistent with our story. These results, combined with those of Table 6, support the hypothesis that at least part of the observed direction of causation comes from the effect of capital shares on investment in human capital and redistribution.

\section{Conclusions}

We have presented a variety of political economy models in an attempt to understand investment in human capital as well as the composition and level of government spending. We have evaluated these models in terms of their capacity to predict the strong relationship existent in the data between most spending variables and capital shares. We have shown that such relationships can be accounted for within the context of a common agency model in which organized labor and capital groups try to influence policies through money contributions. If money is not important for politics and policies are decided by the decisive (median) voter, then a positive relationship between investment in human cap- 
ital and capital shares or between redistribution and capital shares should be present. However, the correlations we find are strongly negative. Empirically, we have shown that the correlation between capital shares and investment in human capital and redistribution is robust to alternative functional specification and controls, and is not due to the existence of outliers. We also show that both Granger causality tests and instrumental variables estimation support the hypothesis that the direction of causation goes from capital shares to government spending and not the other way around.

The recent surge of political economy literature has seen a proliferation of models of politics, many of which are not complementary. Rather, these models often reflect radically different visions of the political process. Despite the different implications of these visions, there has been little work addressing their comparative power in accounting for existing political realities. In fact, work attempting to disentangle the explanatory power of these hypotheses in explaining cross-country variations in policies is to the best of our knowledge nonexistent. In this paper we have attempted to carry out such a comparison. As is always the case with empirical tests, our exercises test not only the median voter and interest groups hypotheses, but also a set of other auxiliary hypotheses. In particular, this paper has tested the combination of two alternative political economy models with a specification of the politico-economic setting in which the salient conflict of interests is between the owners of human capital and the owners of physical capital. The failure of median voter models to account for variations in the data could be attributed to the inappropriateness of the laborcapital conflict as a description of the key politico-economic divide underlying investment in human capital. Further research is necessary to ascertain whether combinations of the median voter model with other plausible characterizations of the basic political economy are able to account for the patterns in the data. On the other hand, the fact that an interest groups model and a vision of the politico-economic process where the conflict between capital and labor is salient are jointly successful at explaining cross-country patterns can also be seen as a confirmation of the significant explanatory power that the capital-labor conflict 
has for understanding the relationship between politics and economics. Models based on the capital-labor divide have often been rightly criticized as simplistic and reductionist. Although these criticisms have appropriately pointed out the failure of class cleavages in explaining a number of political outcomes, our research shows that they can still do quite well in terms of explaining general differences across countries and over time.

\section{$5 \quad$ References}

Aghion, Philippe and Peter Howitt (1998) Endogenous growth theory. Cambridge, MA., MIT Press, 1998.

Alesina, Alberto (1997) "The Political Economy of Macroeconomic Stabilizations and Income Inequality: Myths and Reality," in Tanzi, Vito and Ke-Young Chu, eds. Income Distribution and High-Quality Growth, Cambridge, MA: MIT Press.

Alesina, Alberto and Romain Wacziarg (1998) Openness, Country Size and Government. Journal of Public Economics 69,3 (September): 305-21

Atkinson, A. B. and Joseph Stiglitz (1980) Lectures on Public Economics. New York: Mc Graw-Hill.

Barro, Robert and Xavier Sala-i-Martin (1995) Economic Growth. ( McGraw Hill, New York.)

Bhagwati, Jagdish N., Srinivasan, T. N. and Arvind Panagariya (1998) Lectures on international trade. Cambridge, MA : MIT Press, 1998.

Bernheim, B. Douglas and Whinston, Michael D. (1986) Common Agency. Econometrica 54, 4 (July): 923-42. 
Bernheim, B. Douglas and Whinston, Michael D. (1987) Coalition-Proof Nash Equilibria: Applications Journal of Economic Theory 42(1) : 13-29.

Berheim, B. Douglas. Michael D, Whiston and Bezalel Peleg (1987) CoalitionProof Nash Equilibria: Concepts. Journal of Economic Theory 42(1): 1-12.

Besley, D. A., E. Kuh and R. E. Welsch (1980) Regression Diagnostics. New York: John Wiley and Sons.

Besley, Timothy and Stephen Coate (2001) Lobbying and Welfare in a Representative Democracy. Review of Economic Studies, 68:67-82.

Betancourt, Roger and Christopher Clague (1981) Capital Utilization. Cambridge: Cambridge University Press.

Deiniger, Klaus and Lyn Squire (1996) A New Data Set Measuring Income Inequality World Bank Economic Review, 10(3):565-91.

Deiniger, Klaus and Lyn Squire (1998) New Ways of Looking at Old Issues: Inequality and Growth. Journal of Development Economics 57: 259-87.

Dixit, Avinash K., Gene Grossman and Elhanan Helpman (1997) "Common Agency and Coordination: General Theory and Application to Government Policy Making. " Journal of Political Economy 105(4).

Dixit, Avinash K. and Victor Norman (1980) Theory of International Trade : a Dual, General Equilibrium Approach. Welwyn : Nisbet;: Cambridge University Press.

Doel, I. T. van den (1994) Dynamics in Cross-Section and Panel Data Models. Thesis Publishers, Amsterdam.

Drazen, Allan (2000) Political Economy in Macroeconomics. Princeton: Princeton University Press.

Easterly, William (2001) The Elusive Quest for Growth. Cambridge,MA: MIT Press. 
Goldberg, P. and G. Maggi (1999) "Protection for Sale: An Empirical Investigation," American Economic Review, December 89(5), pages 1135-55.

Gollin, Douglas (2002) Getting Income Shares Right. Journal of Political Economy, 110(2).

Grossman, Gene M. and Elhanan Helpman (1996) Electoral Competition and Special Interest Politics Review of Economic Studies 63, 2 (April): 265-86.

Hillman, Arye L. (1980). The Political Economy of Protection. Chur, Switzerland: Harwood.

Jorgenson, Dale W. and Zvi Grillichees, "Issues in Growth Accounting: A Reply to Edward F. Denison," Survey of Current Business LII (1972), 65-94.

Krueger, Alan B. (1999) "Measuring Labor's Share." American Economic Review, LXXXIX , 45-51.

Krusell, Per and José Victor Ríos-Rull (1999) "On the Size of U.S. Government: Political Economy in the Neoclassical Growth Model," American Economic Review 89(5), December, pages 1156-1181.

Meltzer, Allan and Scott Richard (1981) A Rational Theory of the Size of Government. Journal of Political Economy 89, 914-27.

Meltzer, Allan and Scott Richard , (1983) Tests of a Rational Theory of the Size of Government. Public Choice 41, 403-18.

Mueller, Dennis (1989) Public Choice II: A Revised Edition of Public Choice. Cambridge: Cambridge University Press.

Persson, Torsten and Guido Tabellini (2000) Political Economics: Explaining Economic Policy. Cambridge, Mass., MIT Press.

Pritchett, Lant. (1996) Where Has All the Education Gone? Washington, D.C.: The World Bank, Policy Research Department Working Paper \# 1581. 
Ram, R. (1987) "Wagner's Hypothesis in Time-Series and Cross-Section Perspectives: Evidence form 'Real Data' for 115 Countries," Review of Economics and Statistics 62: 194-204

Rodríguez, Francisco (1998) Essays on the Political Economy of Inequality, redistribution and Growth. PhD Dissertation, Harvard University.

Rodríguez, Francisco (2004) "Factor Shares and Resource Booms: Accounting for the Evolution of Venezuelan Inequality," in Cornia, G. A., ed. Inequality, Growth, and Poverty in an Era of Liberalization and Globalization, Oxford University Press.

Rodrik, Dani (1998) Why Do More Open Economies Have Bigger Governments? Journal of Political Economy 106, 5 (October): 997-1032.

Rowthorn, Bob (1999) "Unemployment, wage-bargaining and capital-labor substitution", Cambridge, Journal of Economics 23: 413-425.

Samuelson, Paul (1964) "Discussion," American Economic Review Papers and Proceedings, 54:9-36.

Scarpa, Carlo (1994) "Regulation as a Bargaining Process: Negotiation over Price and Cost-Reducing Investments". Review of Economic Studies 8: 58-73.

Stolper, Wolfgang and Paul Samuelson (1941) Protection and Real Wages. Review of Economic Studies 8: 58-73.

Wacziarg, Romain (2001) "Human Capital and Democracy," Mimeo, Graduate School of Business, Stanford University.

Wagner, A. (1893) Grundlegung der Politischen Oekonomie, 3rd. ed. Leipzig: C. F. Winter.

Wolff, Edward N. (1996) International Comparisons of Wealth Inequality. Review of Income and Wealth 42(4): 433-451. 
Wolff, Edward N. (1998) Recent Trends in the Size Distribution of Household Wealth. Journal of Economic Perspectives 12(3): 131-50.

World Bank (1999) World Development Indicators CD-Rom. Washington, DC: The World Bank.

Zusman, Pinhas (1976) The Incorporation and Measurement of Social Power in Economic Models. International Economic Review 17 (June):447-62. 


\section{Table 1: Summary Statistics}

\begin{tabular}{|c|c|c|c|c|c|}
\hline & Number of Observations & Mean & Standard Deviation & Minimum & Maximum \\
\hline $\begin{array}{l}\text { Total Spending on Public } \\
\text { Education }\end{array}$ & 328 & 4.444 & 1.890 & 0.500 & 10.700 \\
\hline $\begin{array}{l}\text { Spending on Primary Public } \\
\text { Education }\end{array}$ & 468 & 14.334 & 8.921 & 2.516 & 96.114 \\
\hline $\begin{array}{l}\text { Spending on Secondary Public } \\
\text { Education }\end{array}$ & 199 & 41.364 & 47.492 & 2.352 & 350.365 \\
\hline $\begin{array}{l}\text { Spending on Tertiary Public } \\
\text { Education }\end{array}$ & 317 & 200.717 & 387.155 & 1.752 & 3635.035 \\
\hline Social Security Taxes & 580 & 2.564 & 4.174 & 0.000 & 19.717 \\
\hline Private Health Spending & 126 & 2.111 & 1.267 & 0.081 & 7.850 \\
\hline Public Health Spending & 172 & 3.334 & 2.116 & 0.598 & 8.158 \\
\hline Total Public Investment & 553 & 4.996 & 3.881 & 0.293 & 26.642 \\
\hline Government Consumption & 906 & 14.980 & 5.869 & 4.696 & 48.090 \\
\hline Total Public Spending & 578 & 27.660 & 12.230 & 0.779 & 97.015 \\
\hline Total Population & 1084 & 29058196 & 105915664 & 44026 & 1209363470 \\
\hline $\begin{array}{l}\text { Percentage of Population over } \\
65\end{array}$ & 1039 & 0.052 & 0.037 & 0.011 & 0.177 \\
\hline $\begin{array}{l}\text { Percentage of Population } \\
\text { under } 15\end{array}$ & 1042 & 0.365 & 0.084 & 0.149 & 0.499 \\
\hline Life Expectancy at Birth & 1048 & 59.556 & 12.151 & 32.015 & 79.650 \\
\hline $\begin{array}{l}\text { Expenditure on Primary } \\
\text { Education }\end{array}$ & 345 & 41.707 & 10.313 & 17.214 & 73.130 \\
\hline \begin{tabular}{|l|} 
Expenditure on Secondary \\
Education
\end{tabular} & 345 & 30.024 & 10.344 & 6.102 & 60.571 \\
\hline $\begin{array}{l}\text { Expenditure on Tertiary } \\
\text { Education }\end{array}$ & 388 & 18.615 & 7.357 & 0.222 & 41.186 \\
\hline Democracy & 898 & 0.528 & 0.345 & 0.000 & 1.000 \\
\hline Civil Liberties & 690 & 3.902 & 1.864 & 1.000 & 7.000 \\
\hline Openness & 874 & 65.013 & 43.157 & 6.524 & 378.224 \\
\hline
\end{tabular}




\begin{tabular}{|c|c|c|c|c|c|}
\hline \begin{tabular}{|l} 
Average Years of Total \\
Schooling in the Total \\
Population over age 25 \\
\end{tabular} & 730 & 4.185 & 2.793 & 0.040 & 12.141 \\
\hline Capital Share & 454 & 0.530 & 0.141 & 0.280 & 0.968 \\
\hline $\begin{array}{l}\text { Capital Share, assigning all of } \\
\text { unincorporated enterprises, } \\
\text { income to labor }\end{array}$ & 394 & 0.244 & 0.144 & 0.003 & 0.674 \\
\hline $\begin{array}{l}\text { Capital Share, assigning } 2 / 3 \text { of } \\
\text { unincorporated enterprises' } \\
\text { income to labor }\end{array}$ & 394 & 0.342 & 0.144 & 0.101 & 0.772 \\
\hline $\begin{array}{l}\text { Capital Share assigning } 1 / 3 \text { of } \\
\text { unincorporated enterprises' } \\
\text { income to labor }\end{array}$ & 394 & 0.439 & 0.143 & 0.200 & 0.870 \\
\hline $\begin{array}{l}\text { Capital Share, excluding } \\
\text { depreciation }\end{array}$ & 522 & 0.484 & 0.164 & 0.181 & 0.935 \\
\hline \multicolumn{6}{|l|}{ Capital Share by Region } \\
\hline OECD & 166 & 0.4240 & 0.0911 & 0.2799 & 0.7741 \\
\hline Latin America & 87 & 0.5411 & 0.1068 & 0.2867 & 0.7986 \\
\hline Eastern Europe & 5 & 0.5559 & 0.1787 & 0.4147 & 0.8673 \\
\hline Asia & 54 & 0.5981 & 0.0988 & 0.3867 & 0.7821 \\
\hline Middle East & 56 & 0.6072 & 0.1296 & 0.3856 & 0.9352 \\
\hline Sub Saharan Africa & 79 & 0.6469 & 0.1406 & 0.3832 & 0.9685 \\
\hline
\end{tabular}


Table 2: Baseline Panel Regressions

\begin{tabular}{|c|c|c|c|c|c|c|c|c|c|c|}
\hline & $\begin{array}{l}\text { Total } \\
\text { Spending } \\
\text { on Public } \\
\text { Education }\end{array}$ & $\begin{array}{l}\text { Spending on } \\
\text { Primary } \\
\text { Public } \\
\text { Education }\end{array}$ & $\begin{array}{l}\text { Spending on } \\
\text { Secondary } \\
\text { Public } \\
\text { Education }\end{array}$ & $\begin{array}{l}\text { Spending on } \\
\text { Tertiary } \\
\text { Public } \\
\text { Education }\end{array}$ & $\begin{array}{l}\text { Social } \\
\text { Security } \\
\text { Taxes }\end{array}$ & $\begin{array}{l}\text { Private } \\
\text { Health } \\
\text { Spending }\end{array}$ & $\begin{array}{l}\text { Public } \\
\text { Health } \\
\text { Spending }\end{array}$ & $\begin{array}{l}\text { Total Public } \\
\text { Investment }\end{array}$ & $\begin{array}{l}\text { Government } \\
\text { Consumption }\end{array}$ & $\begin{array}{l}\text { Total } \\
\text { Public } \\
\text { Spending }\end{array}$ \\
\hline Capital Share & $\begin{array}{c}-6.62 \\
(-5.30) \\
\end{array}$ & $\begin{array}{l}-24.16 \\
(-5.23) \\
\end{array}$ & $\begin{array}{c}-4.16 \\
(-.100) \\
\end{array}$ & $\begin{array}{l}503.03 \\
(2.15) \\
\end{array}$ & $\begin{array}{l}-2.08 \\
(-1.53) \\
\end{array}$ & $\begin{array}{c}-1.42 \\
(-.761) \\
\end{array}$ & $\begin{array}{c}-4.97 \\
(-3.11) \\
\end{array}$ & $\begin{array}{c}1.26 \\
(.662) \\
\end{array}$ & $\begin{array}{l}-15.62 \\
(-6.18) \\
\end{array}$ & $\begin{array}{l}-11.68 \\
(-2.19) \\
\end{array}$ \\
\hline Log GDP & $\begin{array}{c}.435 \\
(1.97)\end{array}$ & $\begin{array}{l}.084 \\
(.088)\end{array}$ & $\begin{array}{l}-4.70 \\
(-.660)\end{array}$ & $\begin{array}{l}-50.74 \\
(-1.24)\end{array}$ & $\begin{array}{l}.290 \\
(.903)\end{array}$ & $\begin{array}{c}.282 \\
(.802)\end{array}$ & $\begin{array}{l}.256 \\
(.957)\end{array}$ & $\begin{array}{c}.356 \\
(1.03)\end{array}$ & $\begin{array}{c}.778 \\
(1.51)\end{array}$ & $\begin{array}{l}.906 \\
(.863)\end{array}$ \\
\hline Log Population & $\begin{array}{l}-.043 \\
(-.464)\end{array}$ & $\begin{array}{l}-.515 \\
(-1.00)\end{array}$ & $\begin{array}{l}-3.82 \\
(-1.10)\end{array}$ & $\begin{array}{l}-33.91 \\
(-1.66)\end{array}$ & $\begin{array}{l}.051 \\
(.207)\end{array}$ & $\begin{array}{c}.386 \\
(2.91)\end{array}$ & $\begin{array}{l}-.092 \\
(-.847)\end{array}$ & $\begin{array}{l}-.675 \\
(-3.95)\end{array}$ & $\begin{array}{l}-1.03 \\
(-3.30)\end{array}$ & $\begin{array}{l}-1.95 \\
(-3.37)\end{array}$ \\
\hline $\begin{array}{c}\text { Percentage of } \\
\text { population over } 65\end{array}$ & $\begin{array}{l}18.58 \\
(2.34)\end{array}$ & $\begin{array}{l}95.40 \\
(2.92)\end{array}$ & $\begin{array}{l}100.75 \\
(.311)\end{array}$ & $\begin{array}{l}2239.73 \\
(1.34)\end{array}$ & $\begin{array}{l}48.42 \\
(4.90)\end{array}$ & $\begin{array}{l}-3.11 \\
(-.377)\end{array}$ & $\begin{array}{l}17.62 \\
(1.90)\end{array}$ & $\begin{array}{c}6.17 \\
(.523)\end{array}$ & $\begin{array}{l}52.50 \\
(3.36)\end{array}$ & $\begin{array}{l}259.86 \\
(7.41)\end{array}$ \\
\hline $\begin{array}{c}\text { Percentage of } \\
\text { population under } 14\end{array}$ & $\begin{array}{l}15.26 \\
(4.08)\end{array}$ & $\begin{array}{l}7.24 \\
(.529)\end{array}$ & $\begin{array}{l}-26.45 \\
(-.176)\end{array}$ & $\begin{array}{l}-220.06 \\
(-.289)\end{array}$ & $\begin{array}{l}2.58 \\
(.616)\end{array}$ & $\begin{array}{l}-1.12 \\
(-.229)\end{array}$ & $\begin{array}{c}3.43 \\
(.764)\end{array}$ & $\begin{array}{l}14.13 \\
(2.55)\end{array}$ & $\begin{array}{l}46.91 \\
(6.70)\end{array}$ & $\begin{array}{l}103.92 \\
(6.70)\end{array}$ \\
\hline Life Expectancy & $\begin{array}{c}.061 \\
(1.40) \\
\end{array}$ & $\begin{array}{c}-.287 \\
(-2.01) \\
\end{array}$ & $\begin{array}{c}-1.16 \\
(-1.14) \\
\end{array}$ & $\begin{array}{l}-11.25 \\
(-1.66) \\
\end{array}$ & $\begin{array}{c}-.048 \\
(-1.05) \\
\end{array}$ & $\begin{array}{c}-.019 \\
(-.288) \\
\end{array}$ & $\begin{array}{c}-.025 \\
(-.505) \\
\end{array}$ & $\begin{array}{c}.013 \\
(.236) \\
\end{array}$ & $\begin{array}{c}.038 \\
(.527) \\
\end{array}$ & $\begin{array}{c}.291 \\
(1.81) \\
\end{array}$ \\
\hline \# Observations & 170 & 245 & 110 & 196 & 318 & 69 & 71 & 313 & 377 & 320 \\
\hline R-squared & .459 & .312 & .391 & .539 & .508 & .293 & .816 & .362 & .384 & .548 \\
\hline Hausman Test & $\begin{array}{l}17.85 \\
(.012)\end{array}$ & $\begin{array}{l}61.50 \\
(.000)\end{array}$ & $\begin{array}{l}18.72 \\
(.002)\end{array}$ & $\begin{array}{l}12.61 \\
(.027)\end{array}$ & $\begin{array}{l}27.89 \\
(.000)\end{array}$ & $\begin{array}{c}9.53 \\
(.089)\end{array}$ & $\begin{array}{c}5.74 \\
(.451)\end{array}$ & $\begin{array}{c}5.79 \\
(.327)\end{array}$ & $\begin{array}{c}4.12 \\
(.660)\end{array}$ & $\begin{array}{c}5.35 \\
(.499)\end{array}$ \\
\hline
\end{tabular}

Note: All (Random Effects) estimations include a constant, time and continental dummies.

T-statistics based on Huber-White heteroskedasticity-consistent standard errors in parentheses. For last row, p-values are in parenthes es. 
Table 3: Alternative Specifications

\begin{tabular}{|c|c|c|c|c|c|c|c|c|c|c|c|}
\hline & $\begin{array}{l}\text { Total } \\
\text { Spending } \\
\text { on Public } \\
\text { Education }\end{array}$ & $\begin{array}{l}\text { Spending } \\
\text { on Primary } \\
\text { Public } \\
\text { Education }\end{array}$ & $\begin{array}{l}\text { Spending on } \\
\text { Secondary } \\
\text { Public } \\
\text { Education }\end{array}$ & $\begin{array}{l}\text { Spending } \\
\text { on Tertiary } \\
\text { Public } \\
\text { Education }\end{array}$ & \multicolumn{2}{|c|}{$\begin{array}{l}\text { Social Security } \\
\text { Taxes }\end{array}$} & $\begin{array}{l}\text { Private } \\
\text { Health } \\
\text { Spending }\end{array}$ & $\begin{array}{l}\text { Public } \\
\text { Health } \\
\text { Spending }\end{array}$ & $\begin{array}{l}\text { Total } \\
\text { Public } \\
\text { Investment }\end{array}$ & $\begin{array}{l}\text { Government } \\
\text { Consumption }\end{array}$ & $\begin{array}{l}\text { Total } \\
\text { Public } \\
\text { Spending }\end{array}$ \\
\hline 1.Baseline & $\begin{array}{c}-6.62 \\
(-5.30)\end{array}$ & $\begin{array}{l}-24.16 \\
(-5.23)\end{array}$ & $\begin{array}{c}-4.16 \\
(-.100)\end{array}$ & $\begin{array}{l}503.03 \\
(2.15)\end{array}$ & $\begin{array}{c}-2.08 \\
(-1.53)\end{array}$ & $\begin{array}{l}-.975^{*} \\
(-1.43)\end{array}$ & $\begin{array}{l}-1.42 \\
(-.761)\end{array}$ & $\begin{array}{c}-4.97 \\
(-3.11)\end{array}$ & $\begin{array}{l}1.26 \\
(.662)\end{array}$ & $\begin{array}{l}-15.62 \\
(-6.18)\end{array}$ & $\begin{array}{l}-11.68 \\
(-2.19)\end{array}$ \\
\hline $\begin{array}{l}\text { 2.Fixed } \\
\text { Effects }\end{array}$ & $\begin{array}{c}-6.37 \\
(-1.62) \\
\end{array}$ & $\begin{array}{l}-29.23 \\
(-4.31)\end{array}$ & $\begin{array}{c}-8.61 \\
(-.185)\end{array}$ & $\begin{array}{l}-489.17 \\
(-1.23)\end{array}$ & \multicolumn{2}{|c|}{$\begin{array}{c}-2.93 \\
(-2.29)\end{array}$} & $\begin{array}{c}4.04 \\
(.760)\end{array}$ & $\begin{array}{l}-27.25 \\
(-2.45)\end{array}$ & $\begin{array}{c}3.09 \\
(.818)\end{array}$ & $\begin{array}{l}-20.30 \\
(-3.97)\end{array}$ & $\begin{array}{l}-16.40 \\
(-1.58)\end{array}$ \\
\hline $\begin{array}{l}\text { 3.All variables } \\
\text { in logs }\end{array}$ & $\begin{array}{c}-869 \\
(-4.85)\end{array}$ & $\begin{array}{c}-1.17 \\
(-7.42)\end{array}$ & $\begin{array}{c}-.617 \\
(-1.82)\end{array}$ & $\begin{array}{l}-.111 \\
(-.349)\end{array}$ & \multicolumn{2}{|c|}{$\begin{array}{c}-.357 \\
(-1.02)\end{array}$} & $\begin{array}{c}.062 \\
(.142)\end{array}$ & $\begin{array}{l}-1.05 \\
(-4.06)\end{array}$ & $\begin{array}{c}.059 \\
(.300)\end{array}$ & $\begin{array}{c}-.553 \\
(-7.00)\end{array}$ & $\begin{array}{l}-.283 \\
(-2.97)\end{array}$ \\
\hline $\begin{array}{l}\text { 4.Tax rate in } \\
\text { logs; inverse } \\
\text { of GDP }\end{array}$ & $\begin{array}{c}-1.71 \\
(-5.58)\end{array}$ & $\begin{array}{l}-2.02 \\
(-6.99)\end{array}$ & $\begin{array}{l}-1.10 \\
(-1.80)\end{array}$ & $\begin{array}{c}-.111 \\
(-.190)\end{array}$ & \multicolumn{2}{|c|}{$\begin{array}{l}-3.39 \\
(-4.13)\end{array}$} & $\begin{array}{c}-.053 \\
(-.063)\end{array}$ & $\begin{array}{l}-1.05 \\
(-4.06)\end{array}$ & $\begin{array}{c}-.023 \\
(-.063)\end{array}$ & $\begin{array}{l}-1.03 \\
(-6.80)\end{array}$ & $\begin{array}{l}-.552 \\
(-3.10)\end{array}$ \\
\hline $\begin{array}{l}\text { 5.Outliers } \\
\text { excluded }\end{array}$ & $\begin{array}{c}-7.39 \\
(-7.98)\end{array}$ & $\begin{array}{l}-21.32 \\
(-5.57)\end{array}$ & $\begin{array}{l}-33.45 \\
(-1.63)\end{array}$ & $\begin{array}{l}58.20 \\
(.543)\end{array}$ & \multicolumn{2}{|c|}{$\begin{array}{l}-2.45 \\
(-3.64)\end{array}$} & $\begin{array}{c}-.024 \\
(-.019)\end{array}$ & $\begin{array}{c}-8.44 \\
(-4.36)\end{array}$ & $\begin{array}{l}.517 \\
(.721)\end{array}$ & $\begin{array}{l}-14.49 \\
(-7.72)\end{array}$ & $\begin{array}{l}-16.35 \\
(-4.72)\end{array}$ \\
\hline $\begin{array}{c}\text { 6.Self- } \\
\text { Employed } \\
\text { Excluded }\end{array}$ & $\begin{array}{c}-6.50 \\
(-5.22)\end{array}$ & $\begin{array}{l}-22.79 \\
(-5.14)\end{array}$ & $\begin{array}{l}.652 \\
(.015)\end{array}$ & $\begin{array}{l}479.52 \\
(2.07)\end{array}$ & \multicolumn{2}{|c|}{$\begin{array}{l}-1.54 \\
(-1.33)\end{array}$} & $\begin{array}{c}-3.36 \\
(-1.36)\end{array}$ & $\begin{array}{c}-4.15 \\
(-2.25)\end{array}$ & $\begin{array}{c}1.72 \\
(.839)\end{array}$ & $\begin{array}{l}-12.55 \\
(-5.20)\end{array}$ & $\begin{array}{c}-8.97 \\
(-1.73)\end{array}$ \\
\hline $\begin{array}{c}7.1 / 3 \\
\text { Adjustment }\end{array}$ & $\begin{array}{c}-6.54 \\
(-5.22)\end{array}$ & $\begin{array}{l}-23.82 \\
(-5.30)\end{array}$ & $\begin{array}{c}-2.65 \\
(-.060)\end{array}$ & $\begin{array}{l}503.69 \\
(2.15)\end{array}$ & \multicolumn{2}{|c|}{$\begin{array}{l}-1.65 \\
(-1.41)\end{array}$} & $\begin{array}{c}-3.36 \\
(-1.36)\end{array}$ & $\begin{array}{c}-4.15 \\
(-2.09)\end{array}$ & $\begin{array}{l}1.91 \\
(.916)\end{array}$ & $\begin{array}{l}-13.14 \\
(-5.42)\end{array}$ & $\begin{array}{l}-10.15 \\
(-1.94)\end{array}$ \\
\hline $\begin{array}{c}8.2 / 3 \\
\text { Adjustment }\end{array}$ & $\begin{array}{c}-6.52 \\
(-5.22) \\
\end{array}$ & $\begin{array}{l}-23.34 \\
(-5.23) \\
\end{array}$ & $\begin{array}{l}-.974 \\
(-.022) \\
\end{array}$ & $\begin{array}{l}491.87 \\
(2.11)\end{array}$ & \multicolumn{2}{|c|}{$\begin{array}{l}-1.60 \\
(-1.38) \\
\end{array}$} & $\begin{array}{c}-3.36 \\
(-1.36) \\
\end{array}$ & $\begin{array}{l}-4.15 \\
(-2.09) \\
\end{array}$ & $\begin{array}{c}1.82 \\
(.878) \\
\end{array}$ & $\begin{array}{l}-12.87 \\
(-5.31) \\
\end{array}$ & $\begin{array}{c}-9.57 \\
(-1.83) \\
\end{array}$ \\
\hline $\begin{array}{l}\text { 9.Excluding } \\
\text { Depreciation }\end{array}$ & $\begin{array}{c}-6.28 \\
(-6.11) \\
\end{array}$ & $\begin{array}{l}-20.22 \\
(-4.91) \\
\end{array}$ & $\begin{array}{c}5.32 \\
(.149) \\
\end{array}$ & $\begin{array}{l}497.99 \\
(2.42) \\
\end{array}$ & \multicolumn{2}{|c|}{$\begin{array}{c}-1.98 \\
(-1.84) \\
\end{array}$} & $\begin{array}{r}-1.32 \\
(-.932) \\
\end{array}$ & $\begin{array}{c}-3.83 \\
(-3.12) \\
\end{array}$ & $\begin{array}{c}1.47 \\
(.869) \\
\end{array}$ & $\begin{array}{l}-15.83 \\
(-7.71) \\
\end{array}$ & $\begin{array}{l}-12.20 \\
(-2.82) \\
\end{array}$ \\
\hline $\begin{array}{l}\text { 10. Gollin } \\
\text { adjustment }\end{array}$ & $\begin{array}{c}-2.81 \\
(-0.90)\end{array}$ & $\begin{array}{l}-17.38 \\
(-1.87)\end{array}$ & $\begin{array}{l}-32.53 \\
(-0.38)\end{array}$ & $\begin{array}{c}-165.82 \\
(-1.85)\end{array}$ & \multicolumn{2}{|c|}{$\begin{array}{c}-4.99 \\
(-1.41)\end{array}$} & $(*)$ & $(*)$ & $\begin{array}{c}-1.52 \\
(-0.59)\end{array}$ & $\begin{array}{c}-1.01 \\
(-0.22)\end{array}$ & $\begin{array}{l}18.79 \\
(2.13)\end{array}$ \\
\hline $\begin{array}{c}\text { 11. Our } \\
\text { capital share } \\
\text { (Gollin } \\
\text { sample) } \\
\end{array}$ & $\begin{array}{c}-8.97 \\
(-2.20)\end{array}$ & $\begin{array}{l}-21.47 \\
(-1.49)\end{array}$ & $\begin{array}{l}-77.58 \\
(-0.90)\end{array}$ & $\begin{array}{l}-269.53 \\
(-2.57)\end{array}$ & \multicolumn{2}{|c|}{$\begin{array}{l}-15.21 \\
(-2.94)\end{array}$} & $(*)$ & $(*)$ & $\begin{array}{c}6.71 \\
(1.54)\end{array}$ & $\begin{array}{l}-20.99 \\
(-3.29)\end{array}$ & $\begin{array}{c}5.61 \\
(0.39)\end{array}$ \\
\hline
\end{tabular}

Note: All (Random Effects) estimations include a constant, time and continental dummies.

Row 1 replicates the results from table 1. For Social Security Taxes in Row 1 includes the results from Tobit estimations. Row 2 uses country-specific dummies. In row 3 all variables are in logs. The same is true for row 4 but the inverse of GDP is used instead of its log. Row 5 is the same as row 1 but excluding outliers as described in text. Row 6 uses capital's share with the contribution of unincorporated enterprises (estimated) excluded from capital rent. Row 7 subtracts only 
$1 / 3$ of the contribution of unincorporated enterprises to capital rent. Row 8 subtracts only $2 / 3$ of the contribution of unincorporated enterprises to capital rent. Row 9 excludes depreciation from capital shares. Row 10 uses Gollin's (2002) adjustment for unincorporated income, while row 10 presents our estimate for the restricted sample of 19 countries for which Gollin's data is available. T-statistics based on Huber-White heteroskedasticity-consistent standard errors in parentheses. $(*)$ indicates insufficient observations. 
Table 4: Sensitivity to Alternative Controls

\begin{tabular}{|c|c|c|c|c|c|c|c|c|c|c|}
\hline & \multicolumn{5}{|c|}{ Total Spending on Public Education } & \multicolumn{5}{|c|}{ Spending on Primary Public Education } \\
\hline Capital Share & $\begin{array}{c}-6.62 \\
(-5.30)\end{array}$ & $\begin{array}{c}-6.78 \\
(-5.38)\end{array}$ & $\begin{array}{c}-6.20 \\
(-4.83)\end{array}$ & $\begin{array}{c}-5.89 \\
(-4.64)\end{array}$ & $\begin{array}{l}-5.28 \\
(-3.91)\end{array}$ & $\begin{array}{l}-24.16 \\
(-5.23)\end{array}$ & $\begin{array}{l}-20.78 \\
(-4.45)\end{array}$ & $\begin{array}{l}-24.30 \\
(-5.22)\end{array}$ & $\begin{array}{l}-24.03 \\
(-5.20)\end{array}$ & $\begin{array}{l}-24.51 \\
(-5.34)\end{array}$ \\
\hline Openess & & $\begin{array}{l}.001 \\
(.467)\end{array}$ & & & & & $\begin{array}{c}-.052 \\
(-2.66)\end{array}$ & & & \\
\hline Democracy & & & $\begin{array}{c}.716 \\
(1.33)\end{array}$ & & & & & $\begin{array}{c}-.552 \\
(-.298)\end{array}$ & & \\
\hline $\begin{array}{c}\text { Civil } \\
\text { Liberties }\end{array}$ & & & & $\begin{array}{c}-.262 \\
(-2.38)\end{array}$ & & & & & $\begin{array}{c}-.333 \\
(-.926)\end{array}$ & \\
\hline Human Capital & & & & & $\begin{array}{c}.104 \\
(1.27)\end{array}$ & & & & & $\begin{array}{c}.033 \\
(.094)\end{array}$ \\
\hline $\begin{array}{c}\text { R-squared } \\
\text { (\# Obs.) }\end{array}$ & $\begin{array}{c}.459 \\
(170)\end{array}$ & $\begin{array}{c}.461 \\
(165)\end{array}$ & $\begin{array}{c}.463 \\
(170)\end{array}$ & $\begin{array}{c}.480 \\
(170)\end{array}$ & $\begin{array}{l}.517 \\
(153)\end{array}$ & $\begin{array}{l}.312 \\
(245)\end{array}$ & $\begin{array}{c}.394 \\
(240)\end{array}$ & $\begin{array}{l}.311 \\
(245)\end{array}$ & $\begin{array}{c}.307 \\
(245)\end{array}$ & $\begin{array}{c}.361 \\
(226)\end{array}$ \\
\hline & \multicolumn{5}{|c|}{ Spending on Secondary Public Education } & \multicolumn{5}{|c|}{ Spending on Tertiary Public Education } \\
\hline Capital Share & $\begin{array}{c}-4.16 \\
(-.100)\end{array}$ & $\begin{array}{l}-14.82 \\
(-.325)\end{array}$ & $\begin{array}{l}4.96 \\
(.112)\end{array}$ & $\begin{array}{l}-.131 \\
(-.003)\end{array}$ & $\begin{array}{l}-18.58 \\
(-.421)\end{array}$ & $\begin{array}{l}503.03 \\
(2.15)\end{array}$ & $\begin{array}{l}508.20 \\
(2.08)\end{array}$ & $\begin{array}{c}483.02 \\
(2.03)\end{array}$ & $\begin{array}{l}549.36 \\
(2.31)\end{array}$ & $\begin{array}{c}253.97 \\
(1.51)\end{array}$ \\
\hline Openess & & $\begin{array}{c}-.226 \\
(-1.07)\end{array}$ & & & & & $\begin{array}{c}-.862 \\
(-.763)\end{array}$ & & & \\
\hline Democracy & & & $\begin{array}{l}12.16 \\
(.625)\end{array}$ & & & & & $\begin{array}{l}-51.76 \\
(-.501)\end{array}$ & & \\
\hline $\begin{array}{c}\text { Civil } \\
\text { Liberties }\end{array}$ & & & & $\begin{array}{c}-2.22 \\
(-.679)\end{array}$ & & & & & $\begin{array}{l}-31.37 \\
(-1.56)\end{array}$ & \\
\hline Human Capital & & & & & $\begin{array}{l}.881 \\
(.308)\end{array}$ & & & & & $\begin{array}{c}4.40 \\
(.405)\end{array}$ \\
\hline $\begin{array}{c}\text { R-squared } \\
\text { (\# Obs.) }\end{array}$ & $\begin{array}{c}.391 \\
(110)\end{array}$ & $\begin{array}{l}.390 \\
(109)\end{array}$ & $\begin{array}{c}.390 \\
(110)\end{array}$ & $\begin{array}{c}.387 \\
(110)\end{array}$ & $\begin{array}{l}.331 \\
(97)\end{array}$ & $\begin{array}{l}.539 \\
(196)\end{array}$ & $\begin{array}{l}.541 \\
(193)\end{array}$ & $\begin{array}{c}.537 \\
(196)\end{array}$ & $\begin{array}{c}.538 \\
(196)\end{array}$ & $\begin{array}{c}.655 \\
(184)\end{array}$ \\
\hline
\end{tabular}




\begin{tabular}{|c|c|c|c|c|c|c|c|c|c|c|}
\hline & \multicolumn{5}{|c|}{ Social Security Taxes } & \multicolumn{5}{|c|}{ Total Public Investment } \\
\hline Capital Share & $\begin{array}{l}-2.08 \\
(-1.53) \\
\end{array}$ & $\begin{array}{c}-2.32 \\
(-1.72) \\
\end{array}$ & $\begin{array}{c}-2.17 \\
(-1.65) \\
\end{array}$ & $\begin{array}{c}-2.17 \\
(-1.65) \\
\end{array}$ & $\begin{array}{c}-2.17 \\
(-1.48)\end{array}$ & $\begin{array}{c}1.26 \\
(.662)\end{array}$ & $\begin{array}{c}3.80 \\
(1.87)\end{array}$ & $\begin{array}{c}1.94 \\
(.942)\end{array}$ & $\begin{array}{c}1.79 \\
(.876)\end{array}$ & $\begin{array}{c}.256 \\
(.129)\end{array}$ \\
\hline Openess & & $\begin{array}{c}.012 \\
(1.95)\end{array}$ & & & & & $\begin{array}{l}.026 \\
(3.79)\end{array}$ & & & \\
\hline Democracy & & & $\begin{array}{l}-.268 \\
(-.561)\end{array}$ & & & & & $\begin{array}{l}.370 \\
(.452)\end{array}$ & & \\
\hline $\begin{array}{c}\text { Civil } \\
\text { Liberty }\end{array}$ & & & & $\begin{array}{c}-.034 \\
(-.358)\end{array}$ & & & & & $\begin{array}{l}.043 \\
(.273)\end{array}$ & \\
\hline Human Capital & & & & & $\begin{array}{c}-155 \\
(-1.29)\end{array}$ & & & & & $\begin{array}{c}-303 \\
(-2.25)\end{array}$ \\
\hline $\begin{array}{l}\text { R-squared } \\
\text { (\# Obs.) }\end{array}$ & $\begin{array}{l}.508 \\
(318) \\
\end{array}$ & $\begin{array}{c}.555 \\
(280)\end{array}$ & $\begin{array}{l}.536 \\
(287)\end{array}$ & $\begin{array}{l}.534 \\
(287)\end{array}$ & $\begin{array}{c}.534 \\
(258)\end{array}$ & $\begin{array}{l}.362 \\
(313)\end{array}$ & $\begin{array}{l}.398 \\
(272)\end{array}$ & $\begin{array}{c}341 \\
(280)\end{array}$ & $\begin{array}{c}.342 \\
(280)\end{array}$ & $\begin{array}{c}.424 \\
(255)\end{array}$ \\
\hline & \multicolumn{5}{|c|}{ Government Consumption } & \multicolumn{5}{|c|}{ Total Public Spending } \\
\hline Capital Share & $\begin{array}{l}-15.62 \\
(-6.18) \\
\end{array}$ & \begin{tabular}{|l|}
-11.75 \\
$(-5.12)$ \\
\end{tabular} & $\begin{array}{l}-15.77 \\
(-6.00) \\
\end{array}$ & $\begin{array}{l}-16.64 \\
(-5.98) \\
\end{array}$ & $\begin{array}{l}-15.32 \\
(-5.36) \\
\end{array}$ & $\begin{array}{l}-11.68 \\
(-2.19) \\
\end{array}$ & $\begin{array}{l}-7.24 \\
(-1.51) \\
\end{array}$ & $\begin{array}{r}-13.44 \\
(-2.40) \\
\end{array}$ & \begin{tabular}{|l|}
-13.20 \\
$(-2.37)$ \\
\end{tabular} & $\begin{array}{l}-12.88 \\
(-2.12) \\
\end{array}$ \\
\hline Openess & & $\begin{array}{c}-.014 \\
(-1.36)\end{array}$ & & & & & $\begin{array}{l}.081 \\
(4.10)\end{array}$ & & & \\
\hline Democracy & & & $\begin{array}{c}-.881 \\
(-.898)\end{array}$ & & & & & $\begin{array}{c}-1.91 \\
(-.862)\end{array}$ & & \\
\hline $\begin{array}{c}\text { Civil } \\
\text { Liberty }\end{array}$ & & & & $\begin{array}{l}.081 \\
(.371)\end{array}$ & & & & & $\begin{array}{l}.271 \\
(.626)\end{array}$ & \\
\hline Human Capital & & & & & $\begin{array}{c}.001 \\
(.006) \\
\end{array}$ & & & & & $\begin{array}{c}.016 \\
(.034) \\
\end{array}$ \\
\hline $\begin{array}{c}\text { R-squared } \\
\text { (\# Obs.) }\end{array}$ & $\begin{array}{r}.384 \\
(377) \\
\end{array}$ & $\begin{array}{l}.321 \\
(332) \\
\end{array}$ & $\begin{array}{l}.348 \\
(339) \\
\end{array}$ & $\begin{array}{l}.351 \\
(308) \\
\end{array}$ & $\begin{array}{c}.410 \\
(304) \\
\end{array}$ & $\begin{array}{c}.548 \\
(320) \\
\end{array}$ & $\begin{array}{l}.565 \\
(279) \\
\end{array}$ & $\begin{array}{l}.530 \\
(287) \\
\end{array}$ & $\begin{array}{l}.530 \\
(287) \\
\end{array}$ & $\begin{array}{c}.515 \\
(258) \\
\end{array}$ \\
\hline
\end{tabular}

Note: All (Random Effects) estimations include a constant, time and continental dummies. T-statistics based on Huber-White heteroskedasticity-consistent standard errors in parentheses. 
Table 5: Interactions with Democracy

\begin{tabular}{|c|c|c|c|c|c|c|c|c|c|c|c|}
\hline & & $\begin{array}{l}\text { Total } \\
\text { Spending on } \\
\text { Public } \\
\text { Education }\end{array}$ & $\begin{array}{l}\text { Spending on } \\
\text { Primary } \\
\text { Public } \\
\text { Education }\end{array}$ & $\begin{array}{l}\text { Spending on } \\
\text { Secondary } \\
\text { Public } \\
\text { Education }\end{array}$ & $\begin{array}{l}\text { Spending on } \\
\text { Tertiary } \\
\text { Public } \\
\text { Education }\end{array}$ & $\begin{array}{l}\text { Social Security } \\
\text { Taxes }\end{array}$ & $\begin{array}{l}\text { Private } \\
\text { Health } \\
\text { Spending }\end{array}$ & $\begin{array}{l}\text { Public } \\
\text { Health } \\
\text { Spending }\end{array}$ & $\begin{array}{l}\text { Total Public } \\
\text { Investment }\end{array}$ & $\begin{array}{l}\text { Government } \\
\text { Consumption }\end{array}$ & $\begin{array}{c}\text { Total } \\
\text { Public } \\
\text { Spending }\end{array}$ \\
\hline \multirow[t]{2}{*}{$\begin{array}{c}\text { Linear } \\
\text { interaction }\end{array}$} & Capital Share & $\begin{array}{l}-6.87 \\
(-5.50)\end{array}$ & $\begin{array}{l}-23.10 \\
(-4.91)\end{array}$ & $\begin{array}{l}-3.94 \\
(-.094)\end{array}$ & $\begin{array}{l}585.78 \\
(2.48)\end{array}$ & $\begin{array}{l}-1.83 \\
(-1.34)\end{array}$ & $(*)$ & $(*)$ & $\begin{array}{l}1.59 \\
(.761)\end{array}$ & $\begin{array}{l}-15.27 \\
(-5.74)\end{array}$ & $\begin{array}{l}-12.90 \\
(-2.26)\end{array}$ \\
\hline & Interaction Term & $\begin{array}{c}1.69 \\
(1.86)\end{array}$ & $\begin{array}{l}-3.25 \\
(-1.01)\end{array}$ & $\begin{array}{l}-1.02 \\
(-.307)\end{array}$ & $\begin{array}{l}-308.38 \\
(-1.67)\end{array}$ & $\begin{array}{l}-.721 \\
(-.874)\end{array}$ & $(*)$ & $(*)$ & $\begin{array}{c}.792 \\
(.565)\end{array}$ & $\begin{array}{l}-.620 \\
(-.366)\end{array}$ & $\begin{array}{c}-.299 \\
(-.078)\end{array}$ \\
\hline \multirow[t]{2}{*}{$\begin{array}{c}\text { Discrete } \\
\text { interaction }\end{array}$} & Capital Share & $\begin{array}{l}-6.82 \\
(-5.32)\end{array}$ & $\begin{array}{l}-23.40 \\
(-4.69)\end{array}$ & $\begin{array}{l}-5.95 \\
(-0.14)\end{array}$ & $\begin{array}{l}508.53 \\
(1.95)\end{array}$ & $\begin{array}{l}-1.81 \\
(-1.35)\end{array}$ & $(*)$ & $(*)$ & $\begin{array}{l}1.850 \\
(0.83)\end{array}$ & $\begin{array}{l}-15.77 \\
(-5.80)\end{array}$ & $\begin{array}{l}-13.13 \\
(-2.30)\end{array}$ \\
\hline & Interaction Term & $\begin{array}{c}1.53 \\
(1.68)\end{array}$ & $\begin{array}{l}-3.18 \\
(-0.94)\end{array}$ & $\begin{array}{c}-0.24 \\
(-0.01)\end{array}$ & $\begin{array}{l}-265.36 \\
(-1.35)\end{array}$ & $\begin{array}{c}-0.72 \\
(-0.89)\end{array}$ & $(*)$ & $(*)$ & $\begin{array}{l}0.913 \\
(0.63)\end{array}$ & $\begin{array}{l}-0.646 \\
(-0.38)\end{array}$ & $\begin{array}{l}-0.403 \\
(-0.11)\end{array}$ \\
\hline
\end{tabular}

Note: All (Random Effects) estimations include a constant, time and continental dummies.

T-statistics based on Huber-White heteroskedasticity-consistent standard errors in parentheses. $(*)$ indicates insufficient observations.

Table 6: Non-Linearities in Education Spending.

\begin{tabular}{|c|c|c|c|}
\hline & $\begin{array}{c}\text { Spending on Primary Public } \\
\text { Education }\end{array}$ & $\begin{array}{c}\text { Spending on Secondary } \\
\text { Public Education }\end{array}$ & $\begin{array}{c}\text { Spending on Tertiary } \\
\text { Public Education }\end{array}$ \\
\hline Capital Share & 48.38 & 416.24 & 2564.65 \\
& $(2.37)$ & $(2.19)$ & 102.47 \\
& 5.98 & 29.75 & $(1.78)$ \\
& $(3.21)$ & $-22)$ & -279.22 \\
& -9.95 & $(-2.26)$ & $196)$ \\
\hline Log GDP* Capital Share & $(-3.65)$ & 110 & 196 \\
\hline \# Observations & 245 & & .558 \\
\hline
\end{tabular}

Note: All (Random Effects) estimations include a constant, time and continental dummies.

T-statistics based on Huber-White heteroskedasticity-consistent standard errors in parentheses. 
Table 7.1: Granger Causality Tests with Spending Variables as Dependent Variables.

\begin{tabular}{|c|c|c|c|c|c|}
\hline & $\begin{array}{l}\text { Total } \\
\text { Spending on } \\
\text { Public } \\
\text { Education }\end{array}$ & $\begin{array}{l}\text { Spending on } \\
\text { Primary Public } \\
\text { Education }\end{array}$ & $\begin{array}{l}\text { Social } \\
\text { Security } \\
\text { Taxes }\end{array}$ & $\begin{array}{l}\text { Government } \\
\text { Consumption }\end{array}$ & $\begin{array}{l}\text { Total Public } \\
\text { Spending }\end{array}$ \\
\hline Lag Capital Share & $\begin{array}{l}-4.28 \\
(-4.24)\end{array}$ & $\begin{array}{l}-6.13 \\
(-2.16)\end{array}$ & $\begin{array}{l}-1.31 \\
(-2.25)\end{array}$ & $\begin{array}{l}-2.57 \\
(-1.74)\end{array}$ & $\begin{array}{l}-8.83 \\
(-2.51)\end{array}$ \\
\hline Lag Total Spending on Public Education & $\begin{array}{l}.3262 \\
(4.52)\end{array}$ & & & & \\
\hline Lag Spending on Primary Public Education & & $\begin{array}{c}.636 \\
(13.46) \\
\end{array}$ & & & \\
\hline Lag Social Security Taxes & & & $\begin{array}{c}.984 \\
(52.82) \\
\end{array}$ & & \\
\hline Lag Government Consumption & & & & $\begin{array}{c}.685 \\
(20.94)\end{array}$ & \\
\hline Lag Total Public Spending & & & & & $\begin{array}{c}.718 \\
(18.74)\end{array}$ \\
\hline $\begin{array}{c}\text { R-squared } \\
\text { (\# Observations) }\end{array}$ & $\begin{array}{l}.548 \\
(112)\end{array}$ & $\begin{array}{l}.740 \\
(191)\end{array}$ & $\begin{array}{l}.964 \\
(276)\end{array}$ & $\begin{array}{l}.763 \\
(374)\end{array}$ & $\begin{array}{l}.768 \\
(276)\end{array}$ \\
\hline
\end{tabular}

Note: All (Random Effects) estimations include a constant. T-statistics based on Huber-White heteroskedasticity-consistent standard errors in parentheses. 
Table 7.2: Granger Causality Tests with Capital Shares as Dependent Variables.

\begin{tabular}{|c|c|c|c|c|c|}
\hline & \multicolumn{5}{|c|}{ Dependent Variable: Capital Share } \\
\hline Lag Capital Share & $\begin{array}{c}.829 \\
(20.17)\end{array}$ & $\begin{array}{c}.886 \\
(25.07)\end{array}$ & $\begin{array}{c}.840 \\
(24.67)\end{array}$ & $\begin{array}{c}.898 \\
(34.06)\end{array}$ & $\begin{array}{c}.862 \\
(27.01)\end{array}$ \\
\hline Lag Total Spending on Public Education & $\begin{array}{c}.002 \\
(.955)\end{array}$ & & & & \\
\hline Lag Spending on Primary Public Education & & $\begin{array}{c}.001 \\
(2.12)\end{array}$ & & & \\
\hline Lag Social Security Taxes & & & $\begin{array}{l}-.0009 \\
(-.938)\end{array}$ & & \\
\hline Lag Government Consumption & & & & $\begin{array}{c}.001 \\
(2.25)\end{array}$ & \\
\hline Lag Total Public Spending & & & & & $\begin{array}{l}.0001 \\
(.528)\end{array}$ \\
\hline $\begin{array}{c}\text { R-squared } \\
\text { (\# Observations) }\end{array}$ & $\begin{array}{c}.863 \\
(151)\end{array}$ & $\begin{array}{c}.857 \\
(226)\end{array}$ & $\begin{array}{l}.863 \\
(264)\end{array}$ & $\begin{array}{c}.883 \\
(332)\end{array}$ & $\begin{array}{c}.866 \\
(264)\end{array}$ \\
\hline
\end{tabular}

Note: All (Random Effects) estimations include a constant. T-statistics based on Huber-White heteroskedasticity-consistent standard errors in parentheses. 
Table 8: Instrumental Variables Estimation

\begin{tabular}{|c|c|c|c|c|c|c|c|c|c|c|}
\hline Dependent Variable & Baseline & $\begin{array}{c}\text { First } \\
\text { Differences }\end{array}$ & $\begin{array}{c}\text { 2SLS } \\
\text { Capital Share }\end{array}$ & $\begin{array}{c}\text { 3SLS } \\
\text { Capital Share }\end{array}$ & $\begin{array}{c}\text { GMM } \\
\text { Capital Share }\end{array}$ & \multicolumn{5}{|c|}{$\begin{array}{c}\text { R-squared } \\
\text { (\# Observations) }\end{array}$} \\
\hline $\begin{array}{l}\text { Total Spending on Public } \\
\text { Education }\end{array}$ & $\begin{array}{c}-6.62 \\
(-5.30)\end{array}$ & $\begin{array}{l}-5.43 \\
(-1.42)\end{array}$ & $\begin{array}{l}-46.76 \\
(-1.09)\end{array}$ & & & $\begin{array}{l}.459 \\
(170)\end{array}$ & $\begin{array}{l}.086 \\
(93)\end{array}$ & (90) & & \\
\hline $\begin{array}{l}\text { Spending on Primary } \\
\text { Public Education }\end{array}$ & $\begin{array}{l}-24.16 \\
(-5.23)\end{array}$ & $\begin{array}{l}-31.41 \\
(-4.03)\end{array}$ & $\begin{array}{c}-141.22 \\
(-1.74)\end{array}$ & $\begin{array}{l}-51.05 \\
(-2.64) \\
\end{array}$ & $\begin{array}{l}-26.47 \\
(-2.34) \\
\end{array}$ & $\begin{array}{c}.312 \\
(245) \\
\end{array}$ & $\begin{array}{r}.195 \\
(163) \\
\end{array}$ & $(158)$ & $(158)$ & $(158)$ \\
\hline Social Security Taxes & $\begin{array}{l}-2.08 \\
(-1.53)\end{array}$ & $\begin{array}{l}-2.85 \\
(-2.48)\end{array}$ & $\begin{array}{l}-14.43 \\
(-.969)\end{array}$ & $\begin{array}{l}-6.02 \\
(-1.84)\end{array}$ & $\begin{array}{l}-1.85 \\
(-1.19)\end{array}$ & $\begin{array}{c}.508 \\
(318)\end{array}$ & $\begin{array}{l}.121 \\
(235)\end{array}$ & (199) & (199) & (199) \\
\hline Government Consumption & $\begin{array}{l}-15.62 \\
(-6.18)\end{array}$ & $\begin{array}{l}-17.42 \\
(-4.89)\end{array}$ & $\begin{array}{l}-75.75 \\
(-2.29)\end{array}$ & $\begin{array}{l}-23.73 \\
(-3.28) \\
\end{array}$ & $\begin{array}{l}-30.54 \\
(-4.32)\end{array}$ & $\begin{array}{l}.384 \\
(377)\end{array}$ & $\begin{array}{l}.253 \\
(315)\end{array}$ & $(270)$ & $(270)$ & (270) \\
\hline Total Public Spending & $\begin{array}{l}-11.68 \\
(-2.19) \\
\end{array}$ & $\begin{array}{r}-9.17 \\
(-1.50) \\
\end{array}$ & $\begin{array}{l}-45.67 \\
(-.921) \\
\end{array}$ & $\begin{array}{l}-14.06 \\
(-.922) \\
\end{array}$ & $\begin{array}{r}-38.29 \\
(-3.71) \\
\end{array}$ & $\begin{array}{l}.548 \\
(320) \\
\end{array}$ & $\begin{array}{l}.228 \\
(234) \\
\end{array}$ & $(197)$ & $(197)$ & $(197)$ \\
\hline
\end{tabular}

Note: All estimations are in first differences, except for the baseline regression. They all include a constant and time dummies. T-statistics based on Huber-

White heteroskedasticity-consistent standard errors in parentheses. 
Table 9: First Stage Regressions

\begin{tabular}{|c|c|c|}
\hline & OLS & SUR \\
\hline Terms of trade (totki) & .1705396 & .136474 \\
& $(2.22)$ & $(2.05)$ \\
\hline Log GDP & -.028 & $(-1.42)$ \\
& $(-1.18)$ & -.139 \\
& -.095 & $(-2.15)$ \\
\hline Log Population & $(-1.37)$ & -.842 \\
& -.818 & $(-1.13)$ \\
\hline $\begin{array}{c}\text { Percentage of population } \\
\text { over 65 }\end{array}$ & $(-1.63)$ & .273 \\
& & $(1.21)$ \\
\hline Percentage of population & .274 & \\
under 14 & $(1.39)$ & $(1.61)$ \\
\hline Life Expectancy & & $(230)$ \\
\hline R-squared & .002 & \\
\hline (\# Observations) & $(.748)$ & \\
\hline
\end{tabular}

Note: All estimations are in first differences, include a constant and time dummies.

T-statistics based on Huber-White heteroskedasticity-consistent standard errors in parentheses. 
Figure 1: Partial Correlation Between Public Spending on Education and Capital Shares coef $=-6.6018529$, se $=1.231353, t=-5.36$

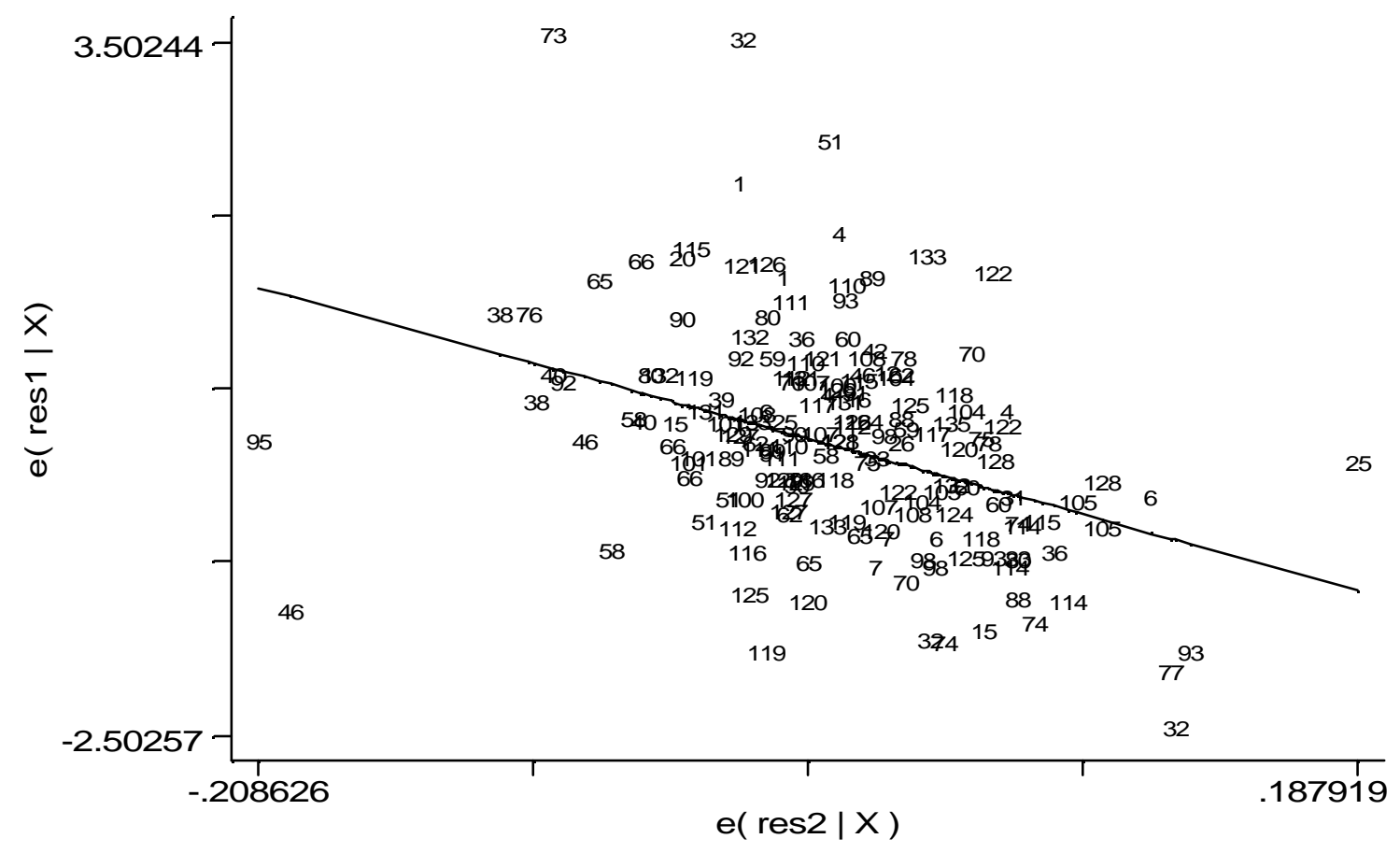


Figure 2: Partial Correlation Between Public Health Spending and Capital Shares

$$
\text { coef }=-6.3340726 \text {, se }=1.6465583, t=-3.85
$$

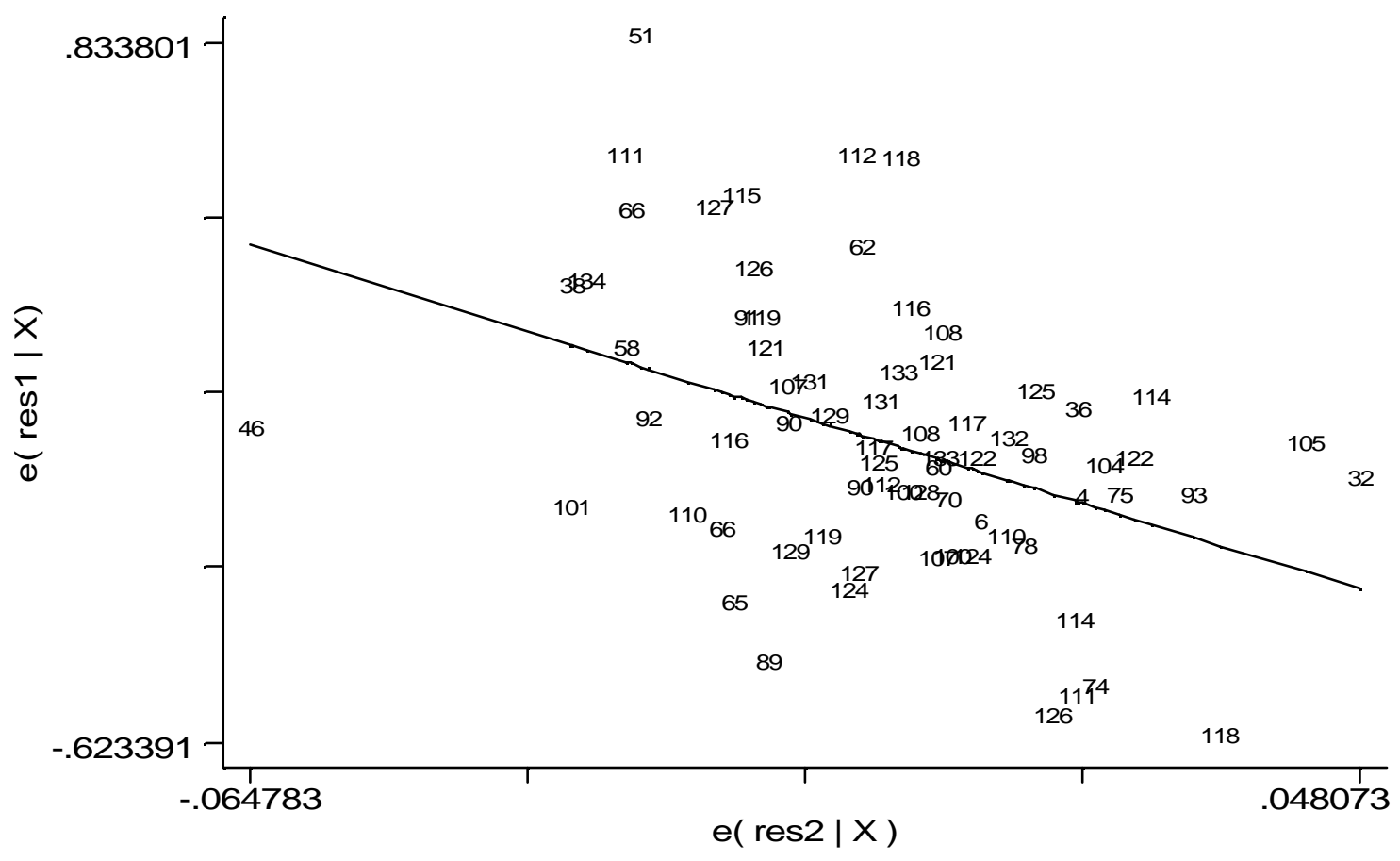

